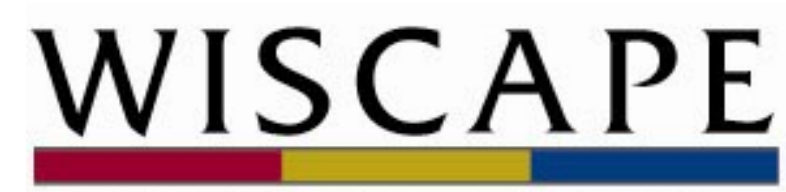

Wisconsin Center for the Advancement

of Postsecondary Education

\title{
The Fiscal Impacts of College Attainment
}

\author{
Philip A. Trostel \\ University of Maine
}

November 2007

\author{
Address correspondence to: \\ Philip Trostel \\ Professor of Economics \& Public Policy \\ Margaret Chase Smith Policy Center \& School of Economics \\ University of Maine \\ 5715 Coburn Hall \\ Orono, ME 04469 \\ E-mail: philip.trostel@maine.edu
}




\section{Table of Contents}

About the Author

Executive Summary

Introduction

Methodology

$\begin{array}{ll}\text { Data } & 10\end{array}$

Basic Approach 11

Timing 13

Tax Rates 18

$\begin{array}{lr}\text { Causation } & 19\end{array}$

College Earnings Premia 20

$\begin{array}{ll}\text { Interstate Migration } & 21\end{array}$

The Effect of Public Support 23

\section{Tax Revenues}

State and Local Taxes $\quad 25$

$\begin{array}{ll}\text { Federal Taxes } & 27\end{array}$

\section{Government Expenditures}

$\begin{array}{lr}\text { Welfare } & 29\end{array}$

Medicaid 33

Medicare $\quad 34$

$\begin{array}{ll}\text { Social Security } & 36\end{array}$

Supplemental Security Income $\quad 38$

$\begin{array}{ll}\text { Unemployment Compensation } & 39\end{array}$

Worker's Compensation $\quad 40$

Corrections. 41

Public Healthcare 44

Public Cost per Degree

Government Spending on College Education 46

Government Cost per Degree. 48

\section{Average Fiscal Rate of Return}

$\begin{array}{ll}\text { Total Fiscal Effects } & 51\end{array}$

$\begin{array}{ll}\text { Fiscal Rates of Return } & 57\end{array}$

$\begin{array}{ll}\text { Conclusion } & 58\end{array}$

$\begin{array}{ll}\text { References } & 61\end{array}$

$\begin{array}{ll}\text { Appendix. } & 65\end{array}$ 


\begin{abstract}
About the Author
Philip A. Trostel is professor in the Department of Economics and the Margaret Chase Smith Center for Public Policy at the University of Maine. He is also a WISCAPE faculty affiliate. Among other things, his research examines how fiscal policies affect the incentives to invest in education and training. His research also explores the quantitative effects of education on wages and employment and the implications for economic growth. For more information, please visit: http://www.umaine.edu/economics/Faculty/Trostel.htm.
\end{abstract}

\title{
Executive Summary
}

This study quantifies the fiscal benefits associated with greater college attainment, one important part of the economic return to public investment in college education. College graduates generally pay much more in taxes than those not going to college, and government expenditures are also generally much less for college graduates than for those without a college education. Indeed, over an average lifetime, total government spending per college degree is negative. That is, direct savings in post-college government expenditures are greater than government expenditures on higher education. Plus, the direct extra tax revenues from college graduates alone are more than six times the gross government cost per college degree. Thus, in addition to the many other benefits from higher education, public financial support of college education pays for itself many times over. On average, government funding for higher education is a sound public investment, even if governments had no other reasons to promote and encourage 
college education and if the higher-education sector produced nothing but collegeeducated taxpayers.

The fiscal effects from college attainment are estimated for numerous federal, state, and local taxes and expenditures. Each four-year-equivalent degree (the weighted average of associate’s, bachelor's, master's, professional, and doctorate degrees, with associate's and master's degrees counting as two-year degrees) creates the following direct fiscal consequences over an average lifetime:

- A total tax revenue increase of about $\$ 471,000$.

Tax revenues increase in the following areas: State income taxes $(\$ 52,500)$, local property taxes $(\$ 38,000)$, state and local sales taxes $(\$ 27,000)$, federal income taxes $(\$ 238,000)$, and federal payroll taxes $(\$ 115,500)$.

- A total government expenditure decrease of $\$ \mathbf{1 0 , 0 0 0}$.

Government expenditures decrease in the following areas: Medicaid $(\$ 21,000)$, Medicare $(\$ 9,500)$, Social Security $(\$ 9,000)$, Supplemental Security Income $(\$ 6,000)$, unemployment compensation $(\$ 1,500)$, worker’s compensation $(\$ 1,500)$, corrections $(\$ 21,000)$, public healthcare $(\$ 5,000)$, and various forms of public assistance $(\$ 10,000)$, for a total of $\$ 84,500$ per degree. Given that total government spending on higher education is about $\$ 74,500$ per degree from public colleges, the net decrease in expenditures is $\$ 10,000$.

\section{- A lifetime net fiscal effect of more than $\$ 481,000$.}

The average annual real internal rate of return on government investment in college students is estimated to be $10.3 \%$. Moreover, this estimate of the average fiscal rate of return is a conservative lower bound. For numerous reasons, the above fiscal 
benefits per college degree are estimated conservatively, while the fiscal costs per degree are estimated generously. Thus, although precise estimation of the numerous fiscal effects and fiscal rate of return is not possible, these estimates clearly demonstrate a substantial payoff to public investment in college education.

The lion's share of the fiscal benefits from college attainment accrues at the federal level. Of the estimated total direct fiscal benefits of \$556,000 per degree, $72.5 \%$ goes to the federal government. The vast majority of the investment cost, however, accrues at the state level, with the federal government providing only about $19 \%$ of the total public support for higher education. Nonetheless, the net fiscal effect per college degree is still positive for individual states. The average net fiscal effect for individual states is, conservatively, almost $\$ 82,000$ per four-year-equivalent degree. The average fiscal rate of return to states is $3.1 \%$. 


\section{Introduction}

Government support for higher education has, arguably, decreased sharply in recent years. ${ }^{1}$ In fiscal year 1984 , nationwide net state funding for higher education was 4.1\% of total state government spending (derived from data from the U.S. Census Bureau's State and Local Government Finances). In 1994, this proportion was 2.4\%, and in 2004, it was 1.8\%. Public investment in higher education is evidently a falling priority. ${ }^{2}$ This has fueled an increasing number of studies highlighting the benefits of investment in college education. The private benefits of college attainment (higher earnings, lower unemployment, better health, etc.) have been overwhelmingly demonstrated and widely publicized. ${ }^{3}$ The wider social benefits from higher education attainment (higher volunteering and civic participation, lower crime, etc.) are not quite as overwhelmingly demonstrated and known, but have become increasingly publicized in recent years. ${ }^{4}$ Prior to this literature, the argument for public support of higher education was based largely on the presumed existence of beneficial externalities that were generally vague, nebulous, and unquantified.

To complement the growing literature on the wider private and social values of higher education, this study quantifies the fiscal impacts of college attainment by focusing on two specific public benefits of higher education: the greater tax revenues from and reduced government spending on college graduates. Thus, this study helps

\footnotetext{
${ }^{1}$ For detailed discussion of this issue, see Longanecker (2006) and Trostel and Ronca (2007).

2 This is at least partly due to increasing fiscal pressures from slow growth in state tax bases and increasing state spending on Medicaid and corrections. See Hovey (1999) and Kane, et al. (2005).

${ }^{3}$ A few of the many examples are Card (1999), Mortenson (2001), Harmon, et al. (2003), Baum and Payea (2004), Institute for Higher Education Policy (2005), and Barrow and Rouse (2005).

${ }^{4}$ Some examples are Haveman and Wolfe (1984), Wolfe and Haveman (2003), Baum and Payea (2004), Lochner and Moretti (2004), McMahon (2004), Rizzo (2004), Topel (2004), and Institute for Higher Education Policy (2005).
} 
address the broad, unanswered issue of the fiscal rate of return to public investments in higher education. As noted above, a huge body of literature is devoted to the private monetary rate of return to investments in education. These studies have generally found a high real rate of return (about 10\%, at least in the United States. And there is a growing literature showing significant non-monetary returns to education, both in private and social terms. But relatively little work quantifies the returns to government investments in higher education. ${ }^{5}$ Some relatively recent studies have quantified the fiscal impacts of college attainment, but mostly only in a rather piecemeal and superficial way. ${ }^{6}$ Given that the 2005 National Income and Product Accounts indicate net federal, state, and local government investment in higher education was $\$ 109$ billion (1\% of national income), this is an important, unanswered policy question.

This study quantifies the fiscal impacts of higher education attainment, a crucial part of the broader issue of the fiscal rate of return to public investments in higher education. This project is narrower than the broad question for two reasons. First, educating students in a state does not necessarily create a corresponding increase in the state's education attainment. Many college graduates migrate to other states, thus creating an interstate fiscal externality. ${ }^{7}$ This issue, however, has been quantified in Trostel (2007), thus it is straightforward to take this into account in this study. Second, the causal effect of state funding for higher education is unclear; changes in public funding for

\footnotetext{
${ }^{5}$ This study is similar to the literature that has quantified the long-term fiscal impacts of government investment in pre-school programs. Some examples of this literature are Currie (2001), Heckman and Masterov (2004), Lynch (2004), and Belfield, et al. (2006). This study is also similar to the recent literature that has quantified the fiscal effects from high school attainment. See, for example, Krop (1998), Vernez, et al. (1999), Goldhaber and Player (2003), Brady et al. (2005), and Levin, et al. (2007).

${ }^{6}$ Some of the fiscal benefits from public investment in college education have been highlighted in Mortenson (1994), Trostel (1997, 2003), Krop (1998), Vernez, et al. (1999), Baum and Payea (2004), Institute for Higher Education Policy (2005), and Brady, et al. (2005).

${ }^{7}$ This is discussed in Strathman (1994).
} 
higher education do not necessarily induce proportionate changes in college attainment. Moreover, the marginal and average effects probably differ. However, although this issue has not been tested directly, recent work by Bound and Turner (2006) suggests a strong causal, and close to proportionate, effect of public funding on college attainment. Direct evidence on the issue of the marginal causal effect of public support on higher education attainment is the subject of current research by the author.

While this is not the first study to show the fiscal effects from public investment in college students, it quantifies these effects more completely and carefully than in previous literature. The most in-depth previous work is the RAND study (Krop, 1998; Vernez, et al., 1999), which, unlike most of the rest of the literature, systematically quantifies almost all of the important fiscal benefits of college attainment and accounts for the important issue of the timing of the fiscal benefits. This study extends the RAND study and the rest of the literature in several ways. First, it takes advantage of a better dataset. Recent data from the U.S. Census Bureau’s Current Population Survey (CPS) provide better estimates of effects on tax revenues, as well as effects on Medicare and Medicaid. The CPS is also a much larger sample than the Survey of Income and Program Participation used in the RAND study, which enables reasonably precise estimation of fiscal effects in individual states. Second, this study estimates separate effects from different levels of college attainment (i.e., associate’s, masters, etc.), quantifies a few more fiscal effects (on worker's compensation and public health spending due to the lack of health insurance), carefully examines the fiscal cost of public support for higher education, and separates state and local fiscal effects from federal fiscal effects. Finally, 
this study is the first to estimate a fiscal rate of return to government investments in college education.

Consistent with the previous literature, public support for higher education is evidently a sound investment of tax dollars. Indeed, the fiscal payoff to public investment in college students appears to be even greater than suggested in the earlier work. Greater college attainment leads to numerous positive fiscal repercussions: increased tax revenues from increased income and reduced low-income tax credits, and decreased expenditures on Medicaid, Medicare, public healthcare, corrections, supplemental security, unemployment compensation, worker's compensation, public assistance, food stamps, the WIC program, housing subsidies, energy assistance, transportation assistance, child-care assistance, and school lunches. Added together, there is a sizable payoff to the government. The average real internal rate of return on government investment in college education appears to be, conservatively, at least $10 \%$. The fiscal rate of return to the federal government is particularly high, conservatively, about 25\%. The average annual real fiscal rate of return to state and local governments, which provide most of the public funding for higher education, is, conservatively, about 3\%. Overall, it is difficult to conceive of another investment that can match this average return to public investment in higher education.

Even if the lack of careful targeting of pubic support for college education causes the marginal fiscal rate of return to be only half of the average rate, the fiscal return to additional public investment in higher education appears to be relatively high. Moreover, this project only quantifies the direct government fiscal benefits from college attainment from public colleges. It does not measure indirect effects on tax revenues and government 
expenditures through higher education's effect on economic growth. The estimated fiscal return also does not include any economic benefits from graduates from private colleges, publicly sponsored university research, university public service and extension activities, or the effect of public colleges and college education on entrepreneurial activity and job creation. Various social benefits, such as higher civic involvement, lower crime, and greater tolerance, are also not quantified.

\section{Methodology}

\section{Data}

As noted previously, the main data source for this study is the CPS, the source of official statistics on employment and unemployment. To be more specific, this study uses the March Annual Social and Economic Supplement (formerly known as the Annual Demographic File), a yearly sample of about 210,000 non-institutionalized individuals. ${ }^{8}$ For individuals age 15 and older, it contains economic and demographic information, such as age, state, education attainment, and various sources of income. Because this study focuses on outcomes after high school, only data from individuals age 19 and older are analyzed. Age is truncated at 80, thus only observations from those 79 and younger are analyzed in this study. The CPS contains about 138,000 observations each year of those between the ages of 19 and 79.

For the following national-level results, this study relies on the latest year of data, 2006, which applies to calendar year 2005. Some cell sizes are quite small for individual states, though (for example, the number people with master's degrees in Vermont

\footnotetext{
${ }^{8}$ The Public Use Microdata Sample of the American Community Survey is a much larger sample but has less-detailed information on sources of income, particularly government transfers and taxes.
} 
receiving food stamps). Thus, following standard Census Bureau practice, for the statelevel results, the latest three years of data (calendar years 2003-2005) are pooled to increase the sample size and reduce sampling variation in the results. Data on taxes, however, are only available for the last two years of data. All dollar values reported in this study are adjusted for inflation using the Consumer Price Index and are expressed in terms of 2005 dollars. All of the following results from CPS data are weighted using CPS sampling weights.

The CPS measures college attainment in terms of degrees (except for those who have some college but no degree). Thus, this project focuses on the fiscal returns from earning college degrees. It would be preferable to quantify the effects in terms of credityears of higher education, but the primary data source does not allow it. Holders of professional and doctorate degrees are small percentages of the CPS sample between the ages of 19 and 79 (1.4\% and 1.2\%, respectively). Thus, these degrees are lumped together to reduce the problem of small cell sizes in individual states.

\section{Basic Approach}

The typical approach in the literature showing the fiscal benefits of education attainment is to calculate average fiscal differentials across education categories. For example, Figure 1 shows average annual labor earnings (including self-employment income) between the ages of 25 and 64 (i.e., prime working years) across education categories. ${ }^{9}$ Average annual earnings across college degrees in Wisconsin are shown in Appendix Table 1. Nationally, those with a high school diploma and no college earned an

\footnotetext{
${ }^{9}$ All results from CPS variables in this report are weighted by the CPS sampling weight.
} 
average of $\$ 24,789$ per year in 2005 . Those with some college earned an additional $\$ 5,652$ per year, on average. The earnings premia of associate’s and bachelor's degrees are $\$ 9,205$ and $\$ 24,264$, respectively. The average earnings premia are $\$ 11,676$ for master’s degrees and $\$ 56,317$ for professional and doctorate degrees (these premia for

Figure 1

Average Labor Earnings and Degree Premia in 2005

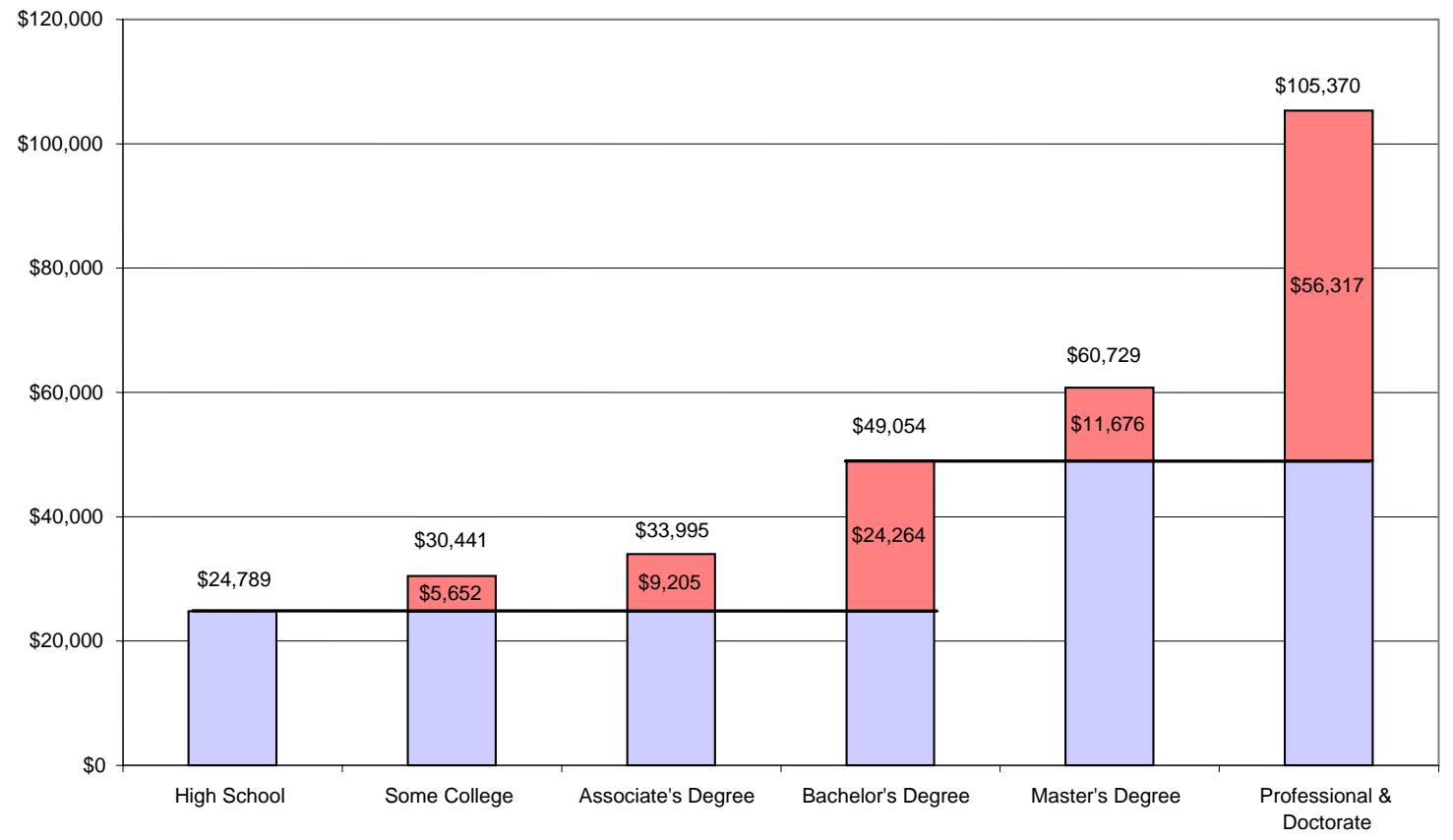

advanced degrees are relative to the prerequisite bachelor's degrees). Nationally, state and local tax revenues are 11\% of personal income in fiscal year 2005 (according to data from the U.S. Census Bureau's State and Local Government Finances and National Income and Product Accounts). Thus, first approximations of the annual college premia in state and local tax revenues are: $\$ 621$ for some college, $\$ 1,011$ for associate’s degrees, $\$ 2,665$ for bachelor’s degrees, $\$ 1,282$ for master’s degrees, and $\$ 6,185$ for professional and doctorate degrees (the corresponding first-pass premia in state and local tax revenues in Wisconsin are shown in Appendix Table 1). That is, a typical holder of a bachelor's 
degree (without a graduate degree) pays $\$ 2,665$ more in state and local taxes than an average high school graduate (with no college); a typical holder of a master's degree pays $\$ 1,282$ more in state and local taxes than an average holder of a bachelor’s degree (without a graduate degree); etc.

These fiscal benefits in terms of tax revenues add up to a substantial sum over a 40-year work career. This sum is substantially greater than the government contribution per degree. Moreover, this is only one of the fiscal benefits from college attainment. However, this is a simplistic approach to quantifying the fiscal effects of public investment in higher education. Numerous factors that could cause this basic approach to be misleading are addressed below.

\section{Timing}

Like practically all other investments, the fiscal benefits of public investment in college students occur for a period of time after the fiscal cost is incurred. This is an obvious and important point, but it is frequently neglected in the nascent literature. In present discounted value, the fiscal benefits of college attainment are not nearly as great as suggested by the above simplistic framework. For example, the average differential in state and local tax revenues per bachelor’s degree sums to $\$ 106,600$ over a 40 -year work career. In present value, though, this is only about $\$ 63,450$ when discounted at a $3 \%$ real interest rate. ${ }^{10}$ Moreover, this is the present value when starting work after college graduation. The present value is noticeably less still at the time when college attendance starts and the fiscal costs are incurred. In addition, college students generally earn less

\footnotetext{
${ }^{10}$ A net-of-inflation interest rate of $3 \%$ is typical in applied economics models.
} 
and pay less in taxes while they are in college. And because this fiscal opportunity cost occurs up-front, it is relatively important in terms of present discounted value.

Perhaps a more subtle issue concerning the timing of the fiscal costs and benefits is that the college earnings premium is not constant over the lifecycle. The average earnings premium is the smallest immediately after graduation, and then increases gradually at a diminishing rate. This is shown in Figure 2, which shows average labor earnings in 2001-2005 (in 2005 dollars) for each age, 25 through 64, and each education qualification. The average life-cycle of labor earnings is clearly steeper early in the careers of those with the most education. ${ }^{11}$ Although the average bachelor's degree premium for those between the ages of 25 and 64 in 2001-2005 is $\$ 25,122$ annually, the premium is clearly much less than this figure early in the work lifecycle. In terms of present value, accounting for this significantly affects the results.

Although discounting future values is simple, the best way to deal with these timing issues is not obvious. Accounting for the timing of the fiscal effects of college attainment requires some assumptions about the average career paths of college graduates, and all sets of assumptions are somewhat problematic in certain dimensions. Instead of following the frequent implicit assumption of constant degree premia over the life-cycle, this study quantifies the degree premia over the life-cycle as the difference in average life-cycle income paths estimated from a fourth-order age polynomial. Following Murphy and Welch (1990), life-cycle variation is captured using quartic age function. Although the CPS is a large sample, it is not large enough to prevent

\footnotetext{
${ }^{11}$ Following standard practice, the absence of cohort effects is implicitly assumed in this discussion. That is, average earnings across ages in a given year are implicitly assumed to reflect average earnings over individual's life-cycles. There is little evidence that possible cohort effects create a misleading picture of life-cycle earnings.
} 
some relatively large sampling variation in mean earnings for each year of age. Such sampling variation is seen clearly in Figure 2, particularly for professional and doctorate degrees because they are a relatively small fraction of the sample. Moreover, the problem is more severe when using fewer years of data, especially for individual small states. Thus, an age polynomial is used to capture life-cycle variation while smoothing the

Figure 2

Average Life Cycle of Labor Earnings in 2001-2005

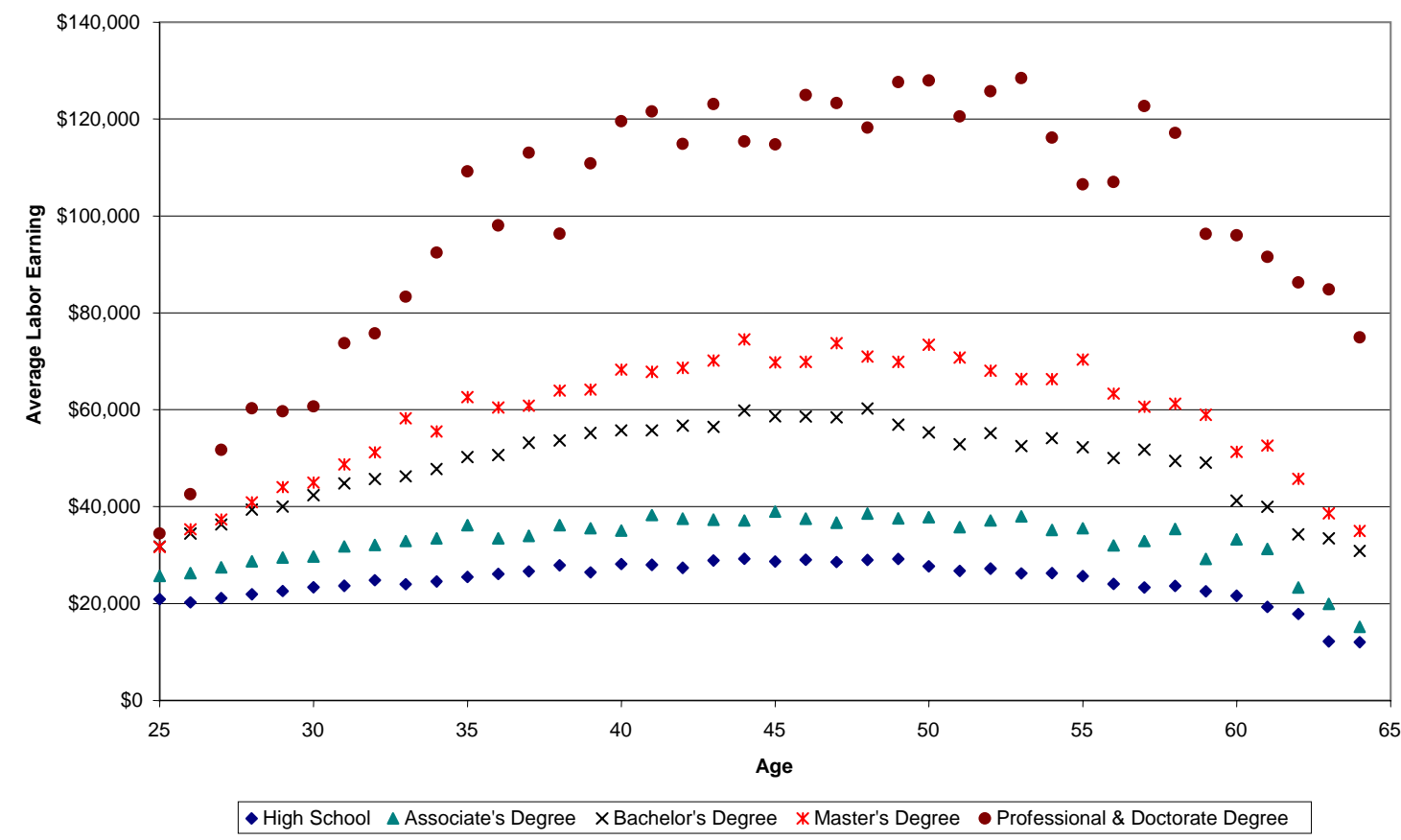

sampling variation. Figure 3 illustrates the estimated life-cycle earnings premia for bachelor’s degrees.

This study makes the simple assumption that the average career paths of graduates are those of traditional students, individuals progressing straight from high school to college and from matriculation to graduation in the standard number of years. To be specific, the work career is assumed to begin at age 19 for high school graduates, 21 for associate’s graduates, 23 for bachelor's graduates, 25 for master's graduates, and 27 for 
professional and doctorate graduates. Associate’s and master's degrees are assumed to take two additional years of education, while bachelor's, professional, and doctorate degrees are assumed to average four additional years of education. This study also makes the simple assumption that students create no fiscal impact while in college other than the direct public cost of higher education. That is, college students are assumed to pay no

Figure 3

Estimated Life-Cycle Profile of Labor Earnings in 2005

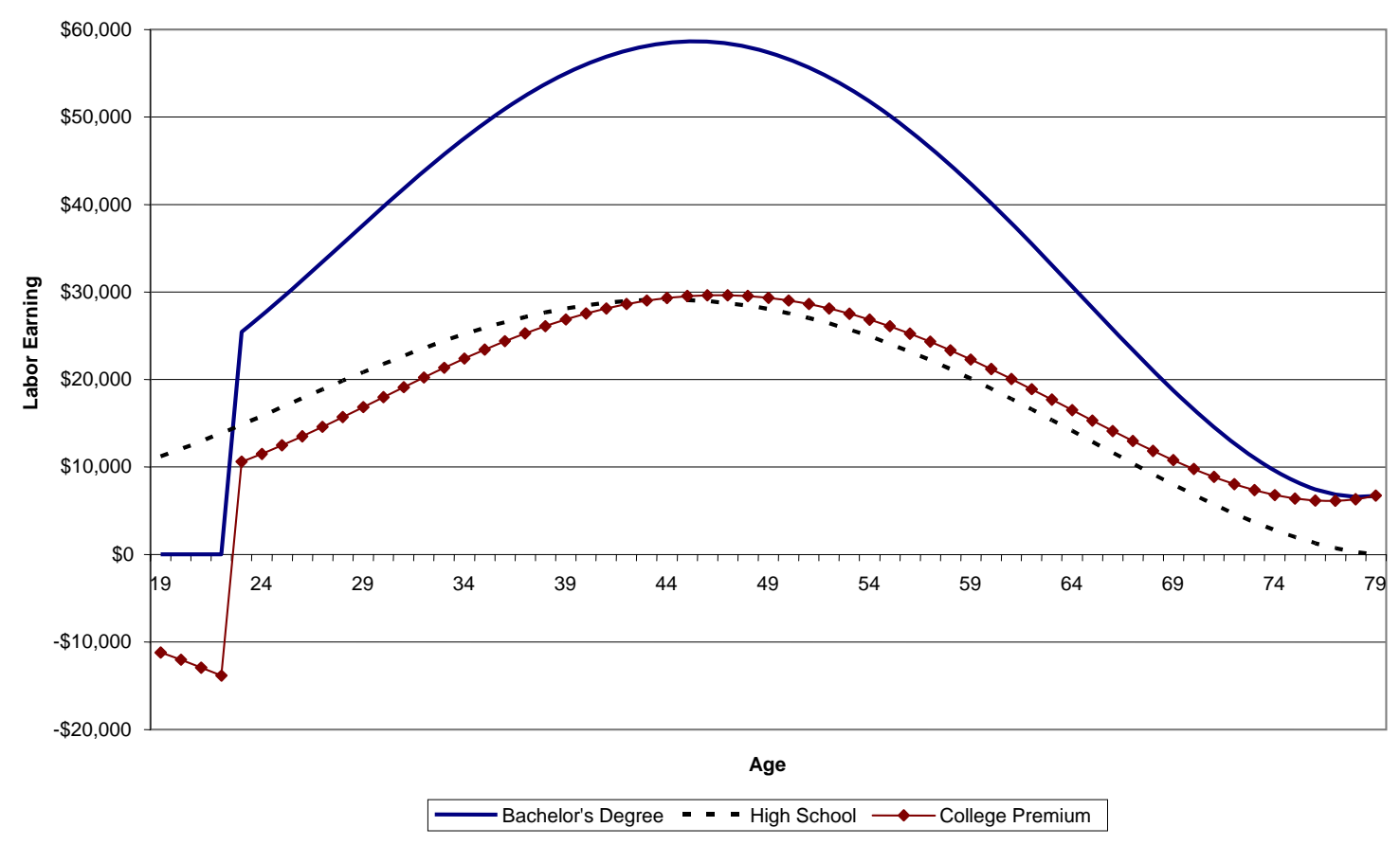

taxes, and to receive the average level of social-insurance payments during college as before and after college. ${ }^{12}$

\footnotetext{
${ }^{12}$ To be specific about assumed social-insurance receipts during college, degree holders are assumed to receive the level of benefits received by average graduates with high school diplomas at age 19, associate's degrees at age 21, bachelor's degrees at age 23, master's degrees at age 25, and the interpolated values at ages 20, 22, 24, and 26. For example, the imputed social-insurance benefits during college for a master's degree is $B^{\mathrm{H}}{ }_{19}+\left(B^{\mathrm{H}}{ }_{19}+B^{\mathrm{A}}{ }_{21}\right)+B^{\mathrm{A}}{ }_{21}+\left(B^{\mathrm{A}}{ }_{21}+B^{\mathrm{B}}{ }_{23}\right)+B^{\mathrm{B}}{ }_{23}+\left(B^{\mathrm{B}}{ }_{23}+B^{\mathrm{M}}{ }_{25}\right)$, where $B$ is the average annual level of benefits, the superscripts $H, A, B$, and M respectively denote high school, associate's degree, bachelor's degree, and master's degree, and the subscripts denote age. Thus, average social-insurance benefits received by college students are assumed to change gradually with college attainment.
} 
Obviously, many college (and high school) students take more than the standard numbers of years to graduate (and some take less than the usual number of years to graduate). Thus, for many college graduates, the benefits of college attainment occur later than assumed above, and the assumption that students are traditional on average overstates the total present value of the fiscal benefits. On the other hand, many students work part-time while in college and/or work full-time while taking time out from college; hence, they pay at least some taxes before college graduation. Presumably, these are the main reasons why many students take longer than usual to graduate. Thus, the assumption that students are traditional on average also understates the total present value of the fiscal benefits. The implicit assumption in this study is that these effects roughly offset each other. To try to quantify these opposing effects would probably add more in complexity and uncertainty than in precision. But it should be clearly acknowledged that this study really quantifies the fiscal impact of traditional college students.

The above set of assumptions is quite conservative in showing the fiscal benefits of public investment in college students for three reasons. First, it ignores any fiscal benefits from those with some college but no degree. As previously stated, this group compared to high school graduates with no college earns \$5,652 more annually and pays \$621 more in state and local taxes per year, on average. The fiscal benefits from some college experience without earning a degree are ignored because of the difficulty in assigning a fiscal cost to this education category. Unlike new college degrees, determining the amount of new individuals with some college experience per year is problematic. 
Second, subsequent results are conservative in showing fiscal benefits of college education because the effect on mortality rates is ignored. Compared to high school graduates, college graduates generally live longer ${ }^{13}$ and hence create greater total fiscal benefits.

Third, the following results are conservative because the intergenerational effects of college education are ignored. That is, compared to high school graduates, the children of college-educated parents are much more likely to become college graduates ${ }^{14}$ and create resulting fiscal benefits.

\section{Tax Rates ${ }^{15}$}

The basic approach presented earlier assumes that taxes are a constant percentage of income. It is unlikely, however, that average tax rates are constant across education categories. Income taxes are generally progressive. Payroll, property, and sales taxes are generally regressive on an annual basis. But most of these are easy to account for using recent CPS data. Beginning in 2005, the CPS has included estimates of individuals' federal income and payroll taxes and state and local income and property taxes. ${ }^{16}$

State and local average sales (and excise) tax rates across education categories can easily be computed using data generated by the Institute on Taxation and Economic Policy’s Microsimulation Tax Model (McIntyre, et al., 2003). To be specific, McIntyre, et al.'s estimates of average sales and excise tax burdens for each income quintile in each

\footnotetext{
${ }^{13}$ See, for example, Lleras-Muney (2005).

${ }^{14}$ See, for example, Haveman and Wolfe (1995).

${ }^{15}$ With the exception of payroll taxes, the burden of taxes is assumed to fall on the payers. The real burden of employers' share of federal payroll taxes is assumed to be borne by workers.

${ }^{16}$ See O’Hara (2004) for information on the CPS procedures used to estimate individuals' tax burdens.
} 
state are matched with individuals’ incomes (excluding transfers) in the CPS. Although the McIntyre, et al. estimates are based on 2002 state tax laws and 2000 income data, this method is far superior to simply applying a uniform average sales tax burden across education categories. McIntyre, et al. shows substantial within-state variation in effective average sales tax rates.

\section{Causation}

The issue of causality is a potentially important problem facing any effort to quantify the effects of educational attainment. Correlation is not causation. Although earnings are highly correlated with education attainment, this does not necessarily prove that more education causes earnings to be higher. It is conceivable that higher-ability and/or higher-motivation individuals generally obtain more education and have greater earnings potential independent of their levels of education. Higher education does not necessarily cause higher earnings or the numerous other outcomes correlated with higher education. The observed correlations may be largely the result of omitted-variables bias (also often referred to as endogeneity bias, or ability bias, in this context).

A large literature has developed to try to identify the causal effect of education on earnings. ${ }^{17}$ A growing literature has also developed trying to identify the causal effect of education on health, mental health, and mortality. ${ }^{18}$ A recent, widely publicized paper by Lochner and Moretti (2004) attempted to identify the causal effect of education on criminal behavior, arrests, and incarceration. Despite the plausibility of the ability-bias

\footnotetext{
${ }^{17}$ See Card (1999) and Harmon, et al. (2003) for recent reviews of this literature.

${ }^{18}$ See Groot and Maassen van den Brink (2004), Cutler and Lleras-Muney (2006), and Chevalier and Feinstein (2006) for recent reviews of this literature.
} 
hypothesis, these literatures have generally demonstrated that the observed correlations are indeed causal effects of education. In fact, many, if not most, of the studies in these literatures find slightly larger causal effects of education than the simple correlations. Thus, it appears that the simple correlations are not misleading; if anything, they appear to be on the conservative side.

This does not mean that the issue of causation can be completely dismissed here. This project examines the correlations between higher education and various outcomes, such as unemployment, welfare participation, and incarceration where causation has either not been tested or tested to only a limited extent. Thus, a potentially important limitation of this project is that it does not necessarily demonstrate causal effects of higher education. Unfortunately, the data used in this project are insufficient to allow for causality testing (testing causality requires unusual datasets, such as samples of twins). Previous research on several different outcomes, however, is certainly suggestive that this may not be an important limitation.

\section{College Earnings Premia}

The basic approach outlined earlier implicitly assumes that college premia are constant. That is, the average earnings differentials (and differentials in other outcomes) between education qualifications are independent of the relative numbers of people with different education levels. A simple supply-and-demand framework, however, suggests that this assumption may be problematic. An increase in the relative supply of collegeeducated labor presumably creates downward pressure on the relative earnings of college-educated labor. Moreover, a relative increase in the supply of college-educated 
labor presumably implies digging deeper into the talent pool of potential college graduates. Thus, it seems plausible that the college premia are not constant as the proportion of college graduates varies. This is an old concern, dating back to the 1976 book The Overeducated American, by Richard Freeman.

Contrary to the predictions in the 1970s, the return to higher education did not fall as more and more Americans obtained college degrees. In fact, the economic return to higher education rose in the 1980s and early 1990s, and has remained roughly stable since the mid-1990s. ${ }^{19}$ Card and Lemieux (2001) and Fortin (2006), however, found that a relative increase in college graduates in a state causes a statistically significant negative effect on the state's college wage premium. On the other hand, using a less-restrictive framework, Trostel (2007) found this effect to be miniscule and not statistically different from zero. Juhn, et al. (2005) also found the effect on the college earnings premium to be very small. Although the issue is not yet settled and is the subject of ongoing research by the author, the effect of the relative supply of college-educated labor on the college earnings premium appears to be no larger than a small second-order effect.

\section{Interstate Migration}

As mentioned earlier, interstate migration of college graduates can cause some state and local investments in college students to end up creating fiscal benefits in other states (of course, the same can be said for state and local investments in primary and secondary students). A state's production of college graduates does not necessarily have a corresponding impact on the state's college attainment. Thus, the fiscal return on a state's

\footnotetext{
${ }^{19}$ For surveys of this literature, see Katz and Autor (1999) and Autor, et al. (2005).
} 
investment in higher education is reduced by the extent of the net interstate migration of its college graduates. The national fiscal return is obviously unaffected by such interstate migration, ${ }^{20}$ but this interjurisdictional spillover reduces the fiscal return to individual states.

Recent research by Trostel (2007) estimates the extent of this interstate spillover of college graduates and thus quantifies the extent that fiscal return to individual states needs to be adjusted downward. That study indicates that the average net loss of a state's new bachelor's degrees to other states is about 7\%. For new associate’s degrees, the net interstate leakage is estimated to be about 3\%. For new master's degrees, the net leakage appears to be about $8 \%$. The net leakage of professional and doctorate degrees to other states is roughly $10 \%$.

Moreover, Trostel (2007) also finds that the net interstate leakage of new college graduates is evidently less for the case of public colleges than for private colleges. With the exception of professional and doctorate degrees, there appears to be no net interstate loss of new graduates from public institutions. The net loss of new professional and doctorate graduates to other states is evidently about the same for public and private institutions (10\%). Because most state support for college students is clearly directed toward those in public institutions, the emphasis in this study is on graduates from public colleges.

Unfortunately, Trostel (2007) did not have sufficient data to identify the net interstate effects for individual states. It is certainly possible that the net interstate spillover of college graduates is larger in some states than in others, but all that can be

\footnotetext{
${ }^{20}$ Net international migration is sufficiently small to ignore. Moreover, accounting for it should show slightly greater fiscal benefits, if anything.
} 
done is to apply the point estimates mentioned above to all states. Specifically, the net reduction in the fiscal benefits of college attainment for individual states is assumed to be 3.4\% for associate’s degrees, 7.1\% for bachelor's degrees, 7.9\% for master's degrees, and 9.6\% for professional and doctorate degrees. Given that the net interstate out-migration of new college graduates is generally less than these percentages for graduates from public colleges, this is a conservative approach (i.e., it yields a lower fiscal rate of return to college education).

These adjustments to the individual-state fiscal benefits of college attainment are only applied to the end calculations of the overall post-college fiscal effects and the fiscal rate of return. Thus, it should be kept in mind that these adjustments are not included in the initial tables showing the various fiscal benefits of college attainment.

\section{The Effect of Public Support}

The causal effect of public support on college attainment is perhaps the most problematic issue confronting an effort to quantify the fiscal return to public investment in college students. Many college graduates do not rely on public support. Undoubtedly there are also many graduates who take advantage of public financial support, but who would have still earned their college degrees without it. Indeed, it has been persuasively argued that public subsidies for higher education often benefit those who would have gone to college anyway. ${ }^{21}$ Thus, the causal effect of public support on college attainment may be significantly less than suggested by the correlation between public support for higher education and the number of graduates from public colleges. In other words,

\footnotetext{
${ }^{21}$ For example, see Hansen and Weisbrod (1969) and Fernandez and Rogerson (1995).
} 
because public higher education subsidies are generally not well targeted at those on the margin of college attendance, the marginal fiscal effect per public dollar invested in higher education may be substantially less than the average fiscal effect.

Although this issue is not addressed directly in a recent study by Bound and Turner (2006), their results suggest a roughly proportionate marginal causal effect of state support for higher education on bachelor's degree production in the state. In other words, their findings indicate that the average relationship between public support and bachelor's degree attainment is not misleading about the causal effect. To be specific, they find that exogenous increases in the number of potential college graduates in a state (high school graduates four years earlier) increases state funding for higher education by about only $60 \%$ of the increase in the number of potential college students (i.e., funding per student falls by 40\%), and it also decreases the number of bachelor's degrees awarded relative to the number of potential college graduates in the state by roughly $40 \%$. Thus, the natural experiment created through changes in cohort size indicates that bachelor's degree attainment in a state changes in inverse proportion to state funding per potential college graduate.

Thus, it tentatively appears that the average correlation between public support and college attainment is not misleading about the causal impact. Current research by the author is attempting to test this tentative conclusion more directly. 


\section{Tax Revenues}

\section{State and Local Taxes}

Table 1 presents estimated lifetime (actually, through age 79) state and local taxes across education categories. ${ }^{22}$ Estimates for Wisconsin are shown in Appendix Table 2. These tables also show lifetime taxes paid in present discounted value (at the start of college at age 19) using a 3\% real interest rate. In addition, they show the total and present-value lifetime degree premia in state and local taxes; that is, the differences in lifetime taxes paid for each degree level relative to those paid by high school graduates (bachelor's graduates in the advanced degree cases). As discussed earlier, these estimates of lifetime taxes are calculated assuming that no taxes are paid from ages 19 through 20 for associate’s degrees, from 19 through 24 for master’s degrees, etc. Also, as noted earlier, the estimates in Table 1 are from 2005 data (Appendix Table 2 is from 2004 and 2005 data measured in 2005 dollars).

Table 1 shows the effects of college attainment on the three types of state and local tax revenues as well as their total. As expected, college education creates substantially more state income tax revenues. Each bachelor’s degree leads to an additional \$55,600 in state income taxes over a lifetime. In present value (at a 3\% discount rate), bachelor’s degree holders pay, on average, 2.5 times as much state income taxes as high school graduates without college. Holders of professional and doctorate degrees pay 4.4 times as much state income taxes in present value as high school degree holder pays only 34\% more property taxes as the average high school graduate with no

\footnotetext{
${ }^{22}$ Tax levels and structures (and levels and structures of social insurance programs) are implicitly assumed to be unaffected by college attainment. Whether fiscal policy depends endogenously on education attainment is an interesting, unexplored issue.
} 
Table 1

Estimated Lifetime State and Local Taxes across Education Categories

\begin{tabular}{|c|c|c|c|c|c|}
\hline & High School & $\begin{array}{c}\text { Associate's } \\
\text { Degree }\end{array}$ & $\begin{array}{r}\text { Bachelor's } \\
\text { Degree }\end{array}$ & $\begin{array}{r}\text { Master's } \\
\text { Degree }\end{array}$ & $\begin{array}{c}\text { Professional \& } \\
\text { Doctorate Degree }\end{array}$ \\
\hline \multicolumn{6}{|l|}{$\underline{\text { Income Taxes }}$} \\
\hline Sum & $\$ 34,044$ & $\$ 50,241$ & $\$ 89,667$ & $\$ 119,138$ & $\$ 168,449$ \\
\hline Present Value & $\$ 15,898$ & $\$ 23,378$ & $\$ 39,760$ & $\$ 49,146$ & $\$ 70,521$ \\
\hline Degree & Sum & $\$ 16,197$ & $\$ 55,624$ & $\$ 29,470$ & $\$ 78,782$ \\
\hline Degree & & $\$ 7,480$ & $\$ 23,862$ & $\$ 9,386$ & $\$ 30,761$ \\
\hline \multicolumn{6}{|l|}{ Property Taxes } \\
\hline $\begin{array}{l}\text { Sum } \\
\text { Present Value }\end{array}$ & $\begin{array}{l}\$ 88,536 \\
\$ 37,549\end{array}$ & $\begin{array}{r}\$ 112,789 \\
\$ 46,791\end{array}$ & $\begin{array}{r}\$ 123,078 \\
\$ 50,256\end{array}$ & $\begin{array}{r}\$ 147,270 \\
\$ 58,025\end{array}$ & $\begin{array}{r}\$ 146,109 \\
\$ 55,632\end{array}$ \\
\hline $\begin{array}{l}\text { Degree } \\
\text { Degree }\end{array}$ & $\begin{array}{l}\text { Sum } \\
\text { PV }\end{array}$ & $\begin{array}{r}\$ 24,253 \\
\$ 9,242\end{array}$ & $\begin{array}{l}\$ 34,542 \\
\$ 12,707\end{array}$ & $\begin{array}{r}\$ 24,192 \\
\$ 7,768\end{array}$ & $\begin{array}{r}\$ 23,031 \\
\$ 5,375\end{array}$ \\
\hline \multicolumn{6}{|l|}{ Sales Taxes } \\
\hline $\begin{array}{l}\text { Sum } \\
\text { Present Value }\end{array}$ & $\begin{array}{l}\$ 57,266 \\
\$ 29,398\end{array}$ & $\begin{array}{l}\$ 71,554 \\
\$ 35,427\end{array}$ & $\begin{array}{l}\$ 85,307 \\
\$ 40,431\end{array}$ & $\begin{array}{l}\$ 93,802 \\
\$ 42,921\end{array}$ & $\begin{array}{r}\$ 120,907 \\
\$ 52,261\end{array}$ \\
\hline $\begin{array}{l}\text { Degree } \\
\text { Degree }\end{array}$ & $\begin{array}{l}\text { Sum } \\
\text { PV }\end{array}$ & $\begin{array}{r}\$ 14,288 \\
\$ 6,029\end{array}$ & $\begin{array}{l}\$ 28,042 \\
\$ 11,033\end{array}$ & $\begin{array}{l}\$ 8,494 \\
\$ 2,490\end{array}$ & $\begin{array}{l}\$ 35,600 \\
\$ 11,830\end{array}$ \\
\hline \multicolumn{6}{|c|}{ Total State and Local Taxes } \\
\hline $\begin{array}{l}\text { Sum } \\
\text { Present Value }\end{array}$ & $\begin{array}{r}\$ 179,845 \\
\$ 82,845\end{array}$ & $\begin{array}{l}\$ 234,584 \\
\$ 105,596\end{array}$ & $\begin{array}{l}\$ 298,053 \\
\$ 130,448\end{array}$ & $\begin{array}{l}\$ 360,209 \\
\$ 150,092\end{array}$ & $\begin{array}{l}\$ 435,465 \\
\$ 178,414\end{array}$ \\
\hline $\begin{array}{l}\text { Degree } \\
\text { Degree }\end{array}$ & $\begin{array}{l}\text { Sum } \\
\text { PV }\end{array}$ & $\begin{array}{l}\$ 54,739 \\
\$ 22,751\end{array}$ & $\begin{array}{r}\$ 118,208 \\
\$ 47,602\end{array}$ & $\begin{array}{l}\$ 62,157 \\
\$ 19,645\end{array}$ & $\begin{array}{r}\$ 137,413 \\
\$ 47,967\end{array}$ \\
\hline
\end{tabular}

Present values are calculated using a $3 \%$ real interest rate.

college. Professional and doctorate degree holders pay only $48 \%$ more in property taxes

over their lifetimes in present value than high school graduates with no college. Sales and excise taxes increase with college attainment in similar proportions as property taxes. In present value, bachelor's degree holders pay 38\% more and professional and doctorate degree holders pay 78\% more sales and excise taxes as high school graduates.

Lifetime total state and local taxes increase by an average of nearly $\$ 55,000$ per associate’s degree, more than $\$ 118,000$ per bachelor's degree, more than $\$ 62,000$ per master’s degree, and more than $\$ 137,000$ for each professional and doctorate degree. The 
present values (using a 3\% discount rate) of these degree premia in state and local tax revenues are, respectively, about $\$ 23,000, \$ 48,000, \$ 20,000$, and $\$ 48,000$.

\section{Federal Taxes}

Estimated lifetime federal taxes across education levels are shown in Table 2. It shows federal income taxes and Social Security payroll taxes (both the employee and employer portions) and their sums. ${ }^{23}$ The patterns of degree premia in lifetime federal income taxes across college education categories are more dramatic than for state income taxes. More specifically, both the absolute and relative sizes of the degree premia for federal income taxes are larger than for state income taxes. Each bachelor's degree leads to an additional $\$ 256,000$ in federal income taxes over a lifetime (compared to $\$ 55,600$ in state income taxes). In present value (at a 3\% discount rate), on average, bachelor’s degree holders pay 3.3 times as much federal income taxes as high school graduates (compared to 2.5 for state income taxes). Holders of professional and doctorate degrees pay 6.4 times as much federal income taxes in present value as high school graduates (compared to 4.4 for state income taxes).

\footnotetext{
${ }^{23}$ Tax levels are implicitly assumed to be constant over time. Persistent federal budget deficits, however, suggest that tax rates will be higher (and/or social-insurance benefit levels will be lower) in the future. To the extent that taxes will be higher (and benefit levels will be lower), these estimates understate the fiscal premia.
} 
Table 2

Estimated Lifetime Federal Taxes across Education Categories

\begin{tabular}{|c|c|c|c|c|c|}
\hline & High School & $\begin{array}{c}\text { Associate's } \\
\text { Degree }\end{array}$ & $\begin{array}{r}\text { Bachelor's } \\
\text { Degree }\end{array}$ & $\begin{array}{r}\text { Master's } \\
\text { Degree } \\
\end{array}$ & $\begin{array}{r}\text { Professional \& } \\
\text { Doctorate Degree }\end{array}$ \\
\hline \multicolumn{6}{|l|}{$\underline{\text { Income Taxes }}$} \\
\hline Sum & $\$ 111,132$ & \multirow{2}{*}{$\begin{array}{l}\$ 194,896 \\
\$ 82,866\end{array}$} & $\$ 367,132$ & $\$ 466,111$ & $\$ 733,428$ \\
\hline Present Value & $\$ 47,255$ & & $\$ 155,699$ & $\$ 190,303$ & $\$ 300,808$ \\
\hline \multicolumn{2}{|c|}{ Degree Premium - Sum } & $\$ 83,764$ & $\$ 255,999$ & $\$ 98,980$ & $\$ 366,297$ \\
\hline \multicolumn{2}{|c|}{ Degree Premium - PV } & $\$ 35,611$ & $\$ 108,444$ & $\$ 34,604$ & $\$ 145,109$ \\
\hline \multicolumn{6}{|c|}{$\underline{\text { Social Security Payroll Taxes }}$} \\
\hline Sum & $\$ 169,398$ & $\$ 223,516$ & $\$ 289,111$ & $\$ 322,247$ & $\$ 482,088$ \\
\hline Present Value & $\$ 86,642$ & $\$ 110,896$ & $\$ 138,423$ & $\$ 148,746$ & $\$ 209,136$ \\
\hline \multirow{2}{*}{\multicolumn{2}{|c|}{$\begin{array}{l}\text { Degree Premium - Sum } \\
\text { Degree Premium - PV }\end{array}$}} & $\$ 54,118$ & $\$ 119,713$ & $\$ 33,136$ & $\$ 192,977$ \\
\hline & & $\$ 24,254$ & $\$ 51,781$ & $\$ 10,323$ & $\$ 70,714$ \\
\hline \multicolumn{6}{|l|}{$\underline{\text { Total }}$} \\
\hline Sum & $\$ 280,531$ & $\$ 418,412$ & $\$ 656,243$ & $\$ 788,358$ & $\$ 1,215,517$ \\
\hline Present Value & $\$ 133,896$ & $\$ 193,761$ & $\$ 294,122$ & $\$ 339,049$ & $\$ 509,945$ \\
\hline \multicolumn{2}{|c|}{$\begin{array}{l}\text { Degree Premium - Sum } \\
\text { Degree Premium - PV }\end{array}$} & $\begin{array}{r}\$ 137,882 \\
\$ 59,865\end{array}$ & $\begin{array}{l}\$ 375,712 \\
\$ 160,225\end{array}$ & $\begin{array}{r}\$ 132,115 \\
\$ 44,927\end{array}$ & $\begin{array}{l}\$ 559,274 \\
\$ 215,823\end{array}$ \\
\hline
\end{tabular}

Present values are calculated using a $3 \%$ real interest rate.

Because of the ceiling on income subject to payroll taxation, the degree premia in lifetime Social Security payroll taxes are not as pronounced as for income taxes. In present value, holders of bachelor's degrees pay only 60\% more payroll taxes as holders of high school diplomas. Professional and doctorate degree holders pay 141\% more payroll taxes over their lifetimes than high school graduates with no college.

In additional average lifetime total federal taxes, an associate’s degree contributes almost $\$ 138,000$, a bachelor’s degree contributes almost $\$ 376,000$, a master’s degree leads to more than $\$ 132,000$, and each professional and doctorate degree leads to more than $\$ 559,000$. The present values (using a 3\% discount rate) of these degree premia in federal taxes are about $\$ 60,000, \$ 160,000, \$ 45,000$, and $\$ 226,000$, respectively. 


\section{Government Expenditures}

\section{Welfare}

This section quantifies the effects of college attainment on various public assistance programs. For each education category, Table 3 shows estimated lifetime (through age 79) income from five public assistance programs: a) food stamps; b) school lunches; ${ }^{24}$ c) various types of public cash assistance; d) energy assistance; and e) housing subsidies. The estimates are for the cash values of these programs in 2005. The sum of these public assistance programs is shown at the bottom of Table 3. As in the case of tax revenues, this table also reports discounted values (at age 19 using a 3\% real interest rate) as well as degree premia in public assistance. The estimates reported in Table 3 are somewhat conservative in that they do not include any public costs in administering these programs. That is, they show the value to the recipients rather than the total fiscal cost.

Table 3 shows that, not surprisingly, college attainment generally leads to lower levels of public assistance. The one exception is the puzzling case of average cash assistance for professional and doctorate degrees, which is somewhat higher than for bachelor's and master's degrees (although less than for high school and associate's degrees). Each bachelor's degree reduces lifetime receipts of food stamps by almost $\$ 7,100$, children’s school lunches by more than $\$ 2,400$, public cash assistance by almost $\$ 1,500$, energy assistance by almost $\$ 400$, housing subsidies by almost $\$ 300$, and total welfare by more than $\$ 11,600$. Total welfare receipts for the average person with a bachelor's degree but without an advanced degree are equal to only $22 \%$ of the cost of

\footnotetext{
${ }^{24}$ Unlike the other programs, school lunches are for the family rather than the individual. It seems appropriate to include the value of school lunches for children.
} 
Working Paper Series

WP012: The Fiscal Impacts of College Attainment

Download at: http://www.wiscape.wisc.edu/publications/WP012

Table 3

Estimated Lifetime Welfare Receipts across Education Categories

\begin{tabular}{ccccc}
\hline & Associate's & Bachelor's & Master's & Professional \& \\
High School & Degree & Degree & Degree & Doctorate Degree \\
\hline
\end{tabular}

Food Stamps

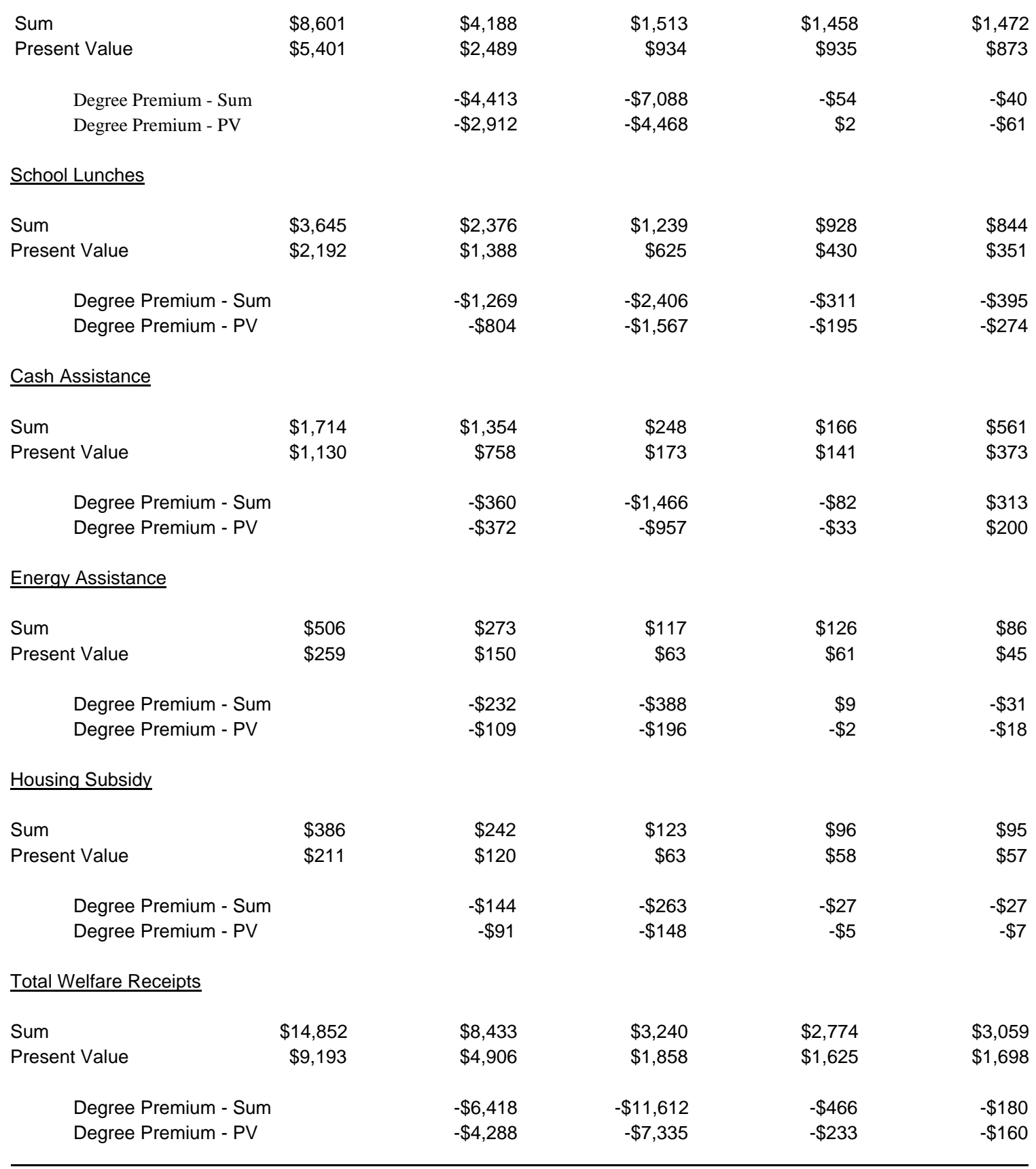

Present values are calculated using a $3 \%$ real interest rate. 
welfare receipts for the average person with a high school diploma and no college. In present discounted value, the average bachelor's degree holder receives $20 \%$ as much as the average high school graduate.

Table 4 Lifetime Average Rates of Receipt of Other Welfare Programs across Education Categories

\begin{tabular}{|c|c|c|c|c|c|}
\hline & High School & $\begin{array}{r}\text { Associate's } \\
\text { Degree }\end{array}$ & $\begin{array}{r}\text { Bachelor's } \\
\text { Degree }\end{array}$ & $\begin{array}{r}\text { Master's } \\
\text { Degree } \\
\end{array}$ & $\begin{array}{r}\text { Professional \& } \\
\text { Doctorate Degree }\end{array}$ \\
\hline WIC & $1.95 \%$ & $1.09 \%$ & $0.41 \%$ & $0.19 \%$ & $0.05 \%$ \\
\hline Degree Differential & & $-0.86 \%$ & $-1.54 \%$ & $-0.22 \%$ & $-0.36 \%$ \\
\hline Childcare Assistance & $0.40 \%$ & $0.47 \%$ & $0.18 \%$ & $0.06 \%$ & $0.06 \%$ \\
\hline Degree Differential & & $0.07 \%$ & $-0.22 \%$ & $-0.12 \%$ & $-0.12 \%$ \\
\hline Transportation Assistance & $0.31 \%$ & $0.26 \%$ & $0.08 \%$ & $0.05 \%$ & $0.07 \%$ \\
\hline Degree Differential & & $-0.05 \%$ & $-0.23 \%$ & $-0.03 \%$ & $0.00 \%$ \\
\hline Work Program & $0.09 \%$ & $0.08 \%$ & $0.03 \%$ & $0.00 \%$ & $0.00 \%$ \\
\hline Degree Differential & & $-0.01 \%$ & $-0.07 \%$ & $-0.03 \%$ & $-0.03 \%$ \\
\hline
\end{tabular}

While the most important types of public assistance are those shown in Table 3, they are not the only ones. The CPS contains information on receiving four other forms of welfare: a) Special Supplemental Nutrition Program for Women, Infants, and Children (WIC); b) childcare assistance; c) transportation assistance; and d) participation in work programs. Unfortunately, it does not contain information on their cash value or fiscal cost. The lifetime incidence of these small, in-kind public assistance programs across college qualifications is shown in Table 4. The pattern of decreasing participation in these programs as higher education qualification increases is similar to the other welfare programs. Compared to the average person with a high school diploma as their highest education in 2005, the average person with a bachelor's degree is $21 \%$ as likely to receive 
WIC, $45 \%$ as likely to receive childcare assistance, $24 \%$ as likely to receive transportation assistance, and 30\% as likely to participate in a work program in order to receive cash assistance. Thus, the total welfare estimates reported at the bottom of Table 3 understate the total degree premia for yet another reason.

Most, but not all, public assistance is funded by the federal government. Moreover, most federal public assistance programs are administered through state governments. As a result of the substantial intergovernmental transfers in welfare spending, a precise decomposition of the fiscal premia into federal and state components is not possible. State and local expenditure data are categorized differently than federal spending data (and they use different fiscal years). State-level data are classified by function, while federal data are classified by agency. Moreover, the state-level data are not disaggregated into programs. Approximate federal/state shares of aggregate welfare spending are constructed by combining the U.S. Census Bureau's Consolidated Federal Funds Report, Federal Aid to States, and State and Local Government Finances. ${ }^{25}$ This indicates that about $78.5 \%$ of total welfare spending is funded at the federal level in fiscal year 2004 (the last year for which federal data are now available). This percentage evidently varies considerably across states, though.

Appendix Table 3 reports the fiscal effects of college attainment for Wisconsin. The estimated state and local share of the fiscal premia in welfare in Wisconsin is $42 \%$ (this is an average for FY 2002 and 2004 because FY 2003 data are not available).

\footnotetext{
${ }^{25}$ To be more specific, federal spending on welfare is derived as the sum of direct payments for food stamps and housing assistance in Consolidated Federal Funds Report plus grants to state and local governments from the Department of Agriculture's Food and Nutrition Service (mostly child nutrition, food stamps, WIC) and from the Department of Health and Human Services' Administration for Children and Families (Temporary Assistance to Needy Families, Head Start, and various other programs) in Federal Aid to States. State and local welfare spending is derived as public welfare less vendor payments (i.e., Medicaid) in State and Local Government Finances, less the federal grants above.
} 


\section{Medicaid}

Medicaid is by far the costliest form of public assistance targeted to the lowincome population. Thus, the fiscal college premium in Medicaid dwarfs those for all other welfare programs combined. This is shown in Table 5. These estimates are for the family market value ${ }^{26}$ of lifetime Medicaid coverage and are derived under the same assumptions as for the other public-assistance programs. The estimates reported in Table 5, like those in Table 3, do not include any public costs in administering Medicaid. In addition, the estimates in Table 5 do not take into account any variation in the use of health care paid with Medicaid. Given that health problems vary inversely with education attainment, presumably the public cost of Medicaid across education attainment varies more than the market value of Medicaid across education attainment. ${ }^{27}$

The pattern of Medicaid received across education levels shown in Table 5 is broadly consistent with the other welfare programs. College attainment reduces spending on Medicaid. The relative amounts that college degrees reduce this type of public assistance are generally somewhat smaller than for the other programs, though. But because Medicaid is so large relative to the other programs, the absolute amounts of fiscal savings are much larger. The average lifetime market value of Medicare received for bachelor's degrees is $45 \%$ as much as for high school diplomas. The present value (at age 19 using a 3\% discount rate) of this differential is almost \$13,200 per bachelor’s

\footnotetext{
${ }^{26}$ Medicaid benefits are for the family rather than the individual because, unlike other forms of public assistance, eligibility rules differ for parents and children, and it seems appropriate (and consistent) to include the Medicaid benefits of children. Also, the CPS measures Medicaid benefits as its insurance market value as opposed to the value of health care bought with Medicaid.

${ }^{27}$ The CPS question about health condition suggests that this could be important. Among recipients of Medicaid age 27 and older, 38\% of those with only a high school education report their health to be very good or excellent, compared to $54 \%$ for those with a bachelor's degree as their highest qualification.
} 
degree, which is 1.8 times larger than for the total of the five public assistance programs shown in Table 3.

Table 5 Estimated Lifetime Market Value of Medicaid across Education Categories

\begin{tabular}{|c|c|c|c|c|c|}
\hline & High School & $\begin{array}{c}\text { Associate's } \\
\text { Degree }\end{array}$ & $\begin{array}{r}\text { Bachelor's } \\
\text { Degree }\end{array}$ & $\begin{array}{r}\text { Master's } \\
\text { Degree }\end{array}$ & $\begin{array}{c}\text { Professional \& } \\
\text { Doctorate Degree }\end{array}$ \\
\hline Sum & $\$ 42,227$ & $\$ 30,786$ & $\$ 19,191$ & $\$ 14,462$ & $\$ 14,154$ \\
\hline Present Value & $\$ 22,912$ & $\$ 15,913$ & $\$ 9,751$ & $\$ 7,565$ & $\$ 6,727$ \\
\hline \multicolumn{2}{|c|}{ Degree Premium - Sum } & $-\$ 11,440$ & $-\$ 23,035$ & $-\$ 4,730$ & $-\$ 5,038$ \\
\hline \multicolumn{2}{|c|}{ Degree Premium - PV } & $-\$ 6,999$ & $-\$ 13,161$ & $-\$ 2,187$ & $-\$ 3,025$ \\
\hline
\end{tabular}

Present values are calculated using a $3 \%$ real interest rate.

In fiscal year 2004, 59.9\% of the national cost of Medicaid was picked up by the federal government (Kaiser Commission on Medicaid and the Uninsured, 2004). Thus, about $40 \%$ of the estimated fiscal premia shown in Table 5 accrue to state governments. This percentage varies among states, though. The rate for Wisconsin is $39 \%$. The resulting estimates of the fiscal premia are shown in Appendix Table 3.

\section{Medicare}

Table 6 reports estimated family market values ${ }^{28}$ of lifetime Medicare benefits across education levels. These average benefit levels are calculated under the same assumptions as for public assistance. These estimates for Medicare and the following estimates for Social Security benefits should be interpreted with additional caution. As mentioned earlier, those with more education tend to live longer than those with less education. Thus, all else being equal, increasing education attainment translates into longer periods of receiving Medicaid and Social Security benefits, and consequently,

\footnotetext{
${ }^{28}$ As with Medicaid, Medicare benefits are for the family rather than for the individual because of the importance of spousal benefits, and Medicare benefits are measured as their insurance market value.
} 
higher fiscal costs. This study does not account for differences in mortality rates, which may cause the fiscal costs of these retirement programs to be biased downward as education attainment increases. This may not make much difference, though, in terms of present discounted value at age $19 .^{29}$

Table 6

Estimated Lifetime Market Value of Medicare across Education Categories

\begin{tabular}{|c|c|c|c|c|c|}
\hline & High School & $\begin{array}{c}\text { Associate's } \\
\text { Degree }\end{array}$ & $\begin{array}{r}\text { Bachelor's } \\
\text { Degree }\end{array}$ & $\begin{array}{r}\text { Master's } \\
\text { Degree } \\
\end{array}$ & $\begin{array}{c}\text { Professional \& } \\
\text { Doctorate Degree }\end{array}$ \\
\hline Sum & $\$ 183,452$ & $\$ 173,941$ & $\$ 179,536$ & $\$ 167,034$ & $\$ 165,884$ \\
\hline Present Value & $\$ 50,592$ & $\$ 42,617$ & $\$ 42,334$ & $\$ 35,515$ & $\$ 32,816$ \\
\hline \multicolumn{2}{|c|}{ Degree Premium - Sum } & $-\$ 9,512$ & $-\$ 3,917$ & $-\$ 12,502$ & $-\$ 13,652$ \\
\hline \multicolumn{2}{|c|}{ Degree Premium - PV } & $-\$ 7,976$ & $-\$ 8,259$ & $-\$ 6,818$ & $-\$ 9,517$ \\
\hline
\end{tabular}

Present values are calculated using a $3 \%$ real interest rate.

Moreover, for two reasons, the approach used in this study might not bias the public costs of retirement programs downward as education attainment increases. As noted in the discussion of Medicaid, the estimates do not take into account any variation in the use of health care paid with Medicare. Thus, given the positive relationship between health and education attainment, this may cause the public cost of Medicare to decrease with education attainment more than the market value of Medicaid decreases with education attainment. ${ }^{30}$ Also, retirement age and the start of receiving retirement benefits increase with education attainment. Hence, it is not necessarily the case that those with more education receive greater retirement benefits because of their longer life expectancies, particularly in present value. Therefore, the net bias of the approach

\footnotetext{
${ }^{29}$ Using a 3\% real discount rate, the present value at age 19 of $\$ 1$ at, say, age 75 , is $\$ 0.19$.

${ }^{30}$ The CPS question about health condition again suggests that this could be important. Among recipients of Medicare, 33\% of those with only a high school education report their health to be very good or excellent, compared to $50 \%$ for those with a bachelor's degree as their highest qualification.
} 
employed in this study is unclear. But the following results for Medicaid and Social Security are more uncertain than the other results in this report.

The estimates reported in Table 6 reveal relatively small differences in the lifetime market value of Medicare across education levels. The differences, though, are a little more noticeable in terms of present value (at age 19 using a 3\% discount rate). Because average retirement age increases with education attainment, each degree level creates present-value fiscal savings in Medicare between about \$6,800 and \$9,500 per degree.

\section{Social Security}

Estimated average lifetime Social Security benefits across education qualifications are reported in Table 7. As noted with Medicare, these estimates should be interpreted with caution. The levels and pattern of lifetime and present-value Social Security benefits are similar to those for Medicare. Average total lifetime (through age 79) benefits are roughly stable across education levels, but the average present value of these benefits generally decreases slightly with education levels. The present-value fiscal premia in Social Security for each degree is between about \$3,800 and \$8,400.

The sum of the fiscal effects of college attainment on Social Security and Medicare are shown in Table 8. The upper set of estimates shows the sum of the lifetime benefits (i.e., the sum of the estimates in Tables 6 and 7). The lower set of estimates shows the lifetime benefits net of lifetime payroll taxes (i.e., the sum of the estimates in Tables 6 and 7 less the estimates in Table 2). This lower set of estimates reports the 
negative of the net average fiscal effect of college attainment on the Social Security program. The net college premia in Social Security and Medicare are large: on average, each bachelor's degree creates net fiscal savings in Social Security and Medicare of almost $\$ 131,000$ over a lifetime. In present value, this net fiscal savings is about $\$ 68,500$. Each professional and doctorate degree creates a lifetime net fiscal savings of more than $\$ 196,000$ and about $\$ 84,000$ in present discounted value (at age 19).

Table 7 Estimated Lifetime Social Security Benefits across Education Categories

\begin{tabular}{|c|c|c|c|c|c|}
\hline & High School & $\begin{array}{c}\text { Associate's } \\
\text { Degree } \\
\end{array}$ & $\begin{array}{r}\text { Bachelor's } \\
\text { Degree } \\
\end{array}$ & $\begin{array}{r}\text { Master's } \\
\text { Degree }\end{array}$ & $\begin{array}{c}\text { Professional \& } \\
\text { Doctorate Degree }\end{array}$ \\
\hline Sum & $\$ 180,557$ & $\$ 174,288$ & $\$ 173,404$ & $\$ 161,467$ & $\$ 183,655$ \\
\hline Present Value & $\$ 44,186$ & $\$ 38,558$ & $\$ 35,763$ & $\$ 30,014$ & $\$ 31,971$ \\
\hline \multicolumn{2}{|c|}{ Degree Premium - Sum } & $-\$ 6,269$ & $-\$ 7,153$ & $-\$ 11,937$ & $\$ 10,251$ \\
\hline \multicolumn{2}{|c|}{ Degree Premium - PV } & $-\$ 5,628$ & $-\$ 8,423$ & $-\$ 5,749$ & $-\$ 3,792$ \\
\hline
\end{tabular}

Present values are calculated using a $3 \%$ real interest rate.

Table 8

Estimated Lifetime Social Security and Medicare Benefits and Net Benefits across Education Categories

High School

Associate's $\quad$ Bachelor's $\quad$ Master's $\quad$ Professional \&

$\underline{\text { Total Social Security \& Medicare Benefits }}$

\begin{tabular}{|c|c|c|c|c|c|}
\hline Sum & $\$ 364,010$ & $\$ 348,229$ & $\$ 352,940$ & $\$ 328,501$ & $\$ 349,539$ \\
\hline Present Value & $\$ 94,778$ & $\$ 81,174$ & $\$ 78,096$ & $\$ 65,529$ & $\$ 64,787$ \\
\hline Degree & & $-\$ 15,781$ & $-\$ 11,070$ & $-\$ 24,439$ & $-\$ 3,401$ \\
\hline Degree & & $-\$ 13,604$ & $-\$ 16,682$ & $-\$ 12,567$ & $-\$ 13,309$ \\
\hline
\end{tabular}

$\underline{\text { Total Benefits Net of Payroll Taxes }}$

\begin{tabular}{|c|c|c|c|c|c|}
\hline Sum & $\$ 194,611$ & $\$ 124,713$ & $\$ 63,829$ & $\$ 6,254$ & $-\$ 132,549$ \\
\hline Present Value & $\$ 8,137$ & $-\$ 29,721$ & $-\$ 60,326$ & $-\$ 83,217$ & $-\$ 144,349$ \\
\hline \multicolumn{2}{|c|}{ Degree Premium - Sum } & $-\$ 69,898$ & $-\$ 130,783$ & $-\$ 57,574$ & $-\$ 196,378$ \\
\hline \multicolumn{2}{|c|}{ Degree Premium - PV } & $-\$ 37,858$ & $-\$ 68,463$ & $-\$ 22,891$ & $-\$ 84,023$ \\
\hline
\end{tabular}

Present values are calculated using a $3 \%$ real interest rate. 


\section{Supplemental Security Income}

Estimated average lifetime receipts of Supplemental Security Income (SSI) across college qualifications are reported in Table $9 .{ }^{31}$ The pattern is similar to that for the various public assistance programs shown in Table 3 and 4 . The fiscal burden of this federal program falls as college attainment increases. As is the case for most of the public assistance programs, most of the impact of college education in SSI payments is for the Table 9 Estimated Lifetime Supplemental Security Income across Education Categories

\begin{tabular}{|c|c|c|c|c|c|}
\hline & High School & $\begin{array}{r}\text { Associate's } \\
\text { Degree } \\
\end{array}$ & $\begin{array}{r}\text { Bachelor's } \\
\text { Degree } \\
\end{array}$ & $\begin{array}{r}\text { Master's } \\
\text { Degree } \\
\end{array}$ & $\begin{array}{r}\text { Professional \& } \\
\text { Doctorate Degree }\end{array}$ \\
\hline Sum & $\$ 9,386$ & $\$ 5,141$ & $\$ 3,330$ & $\$ 3,116$ & $\$ 1,724$ \\
\hline Present Value & $\$ 4,433$ & $\$ 2,077$ & $\$ 1,137$ & $\$ 1,038$ & $\$ 677$ \\
\hline \multicolumn{2}{|c|}{ Degree Premium - Sum } & $-\$ 4,245$ & $-\$ 6,056$ & $-\$ 214$ & $-\$ 1,606$ \\
\hline \multicolumn{2}{|c|}{ Degree Premium - PV } & $-\$ 2,355$ & $-\$ 3,296$ & $-\$ 98$ & $-\$ 460$ \\
\hline
\end{tabular}

Present values are calculated using a $3 \%$ real interest rate.

undergraduate degrees. Average lifetime SSI for holders of bachelor's degrees is $35 \%$ as much as the average lifetime benefits for holders of high school diplomas and no college. In present value, bachelor's degrees holders receive only $26 \%$ as much SSI as recipients of high school diplomas. Each associate’s degree reduces SSI payments by about $\$ 2,400$, and each bachelor’s degree reduces SSI by approximately $\$ 3,300$, also in present value. Master’s degrees, however, reduce the present value of SSI by only an additional $\$ 100$, and professional and doctorate degrees reduce the present value of SSI payments by an additional \$500.

\footnotetext{
${ }^{31}$ The relationship between college education and work disabilities is similar to the relationship between college education and heath. CPS data indicate that for those aged 27 and older, 24 percent of those with only a high school education report a disability or health problem that limits their ability to work, compared to 15 percent of those with a bachelor's degree as their highest qualification.
} 


\section{Unemployment Compensation}

The incidence of unemployment decreases dramatically with college attainment. The unemployment rate in 2005 was 4.55\% among those with a high school education and no college, 3.21\% among those with an associate's degree as their highest education qualification, 2.64\% among those with a bachelor's degree and no advanced degree, 2.03\% among master’s degrees holders, and 1.55\% among those with professional and doctorate degrees. ${ }^{32}$ Thus, college attainment creates fiscal savings in unemployment insurance (UI). However, the relative magnitude of the fiscal savings is not as great as suggested by the differences in unemployment rates because unemployment compensation is partially tied to pre-unemployment earnings, and earnings are clearly related to college attainment.

Table 10 reports average lifetime unemployment compensation across education categories. Corresponding estimates for Wisconsin (using data from 2003-2005 expressed in 2005 dollars) are reported in Appendix Table 3. ${ }^{33}$ These estimates are derived under the assumption that no UI compensation is received while in college. Given the underlying simplifying assumption that degrees are earned by traditional fulltime students, it would be inconsistent to assume that some students receive unemployment benefits by actively seeking employment after losing a job while in college. Unlike the fiscal degree premia in SSI just shown, the estimated fiscal degree premia in UI is small for associate’s degrees, but relatively large for advanced degrees.

\footnotetext{
32 These unemployment rates across education categories are calculated for those within the ages of 27 and 79 using the CPS Historic Earner Study (formerly known as the Outgoing Rotation Groups).

${ }^{33}$ For simplicity, the fact that some unemployment compensation is paid by the federal government is ignored. In most years the federal proportion is relatively small.

${ }^{34}$ Unemployment taxes are ignored in the calculations because employers bear the statutory liability. However, the real incidence of the tax may fall on employees to some extent.
} 
The present value of average lifetime UI compensation for those with bachelor's degrees as their highest education qualification is $66 \%$ as much as that for those with high school as their highest qualification. The present value of average UI compensation for those with professional and doctorate degrees is $12 \%$ as much as that for those with high school Table 10 Estimated Lifetime Unemployment Compensation across Education Categories

\begin{tabular}{|c|c|c|c|c|c|}
\hline & High School & $\begin{array}{c}\text { Associate's } \\
\text { Degree }\end{array}$ & $\begin{array}{r}\text { Bachelor's } \\
\text { Degree } \\
\end{array}$ & $\begin{array}{r}\text { Master's } \\
\text { Degree } \\
\end{array}$ & $\begin{array}{c}\text { Professional \& } \\
\text { Doctorate Degree }\end{array}$ \\
\hline Sum & $\$ 6,689$ & $\$ 6,690$ & $\$ 4,846$ & $\$ 3,508$ & $\$ 880$ \\
\hline Present Value & $\$ 3,443$ & $\$ 3,355$ & $\$ 2,262$ & $\$ 1,616$ & $\$ 417$ \\
\hline \multicolumn{2}{|c|}{ Degree Premium - Sum } & $\$ 1$ & $-\$ 1,842$ & $-\$ 1,338$ & $-\$ 3,967$ \\
\hline \multicolumn{2}{|c|}{ Degree Premium - PV } & $-\$ 88$ & $-\$ 1,182$ & $-\$ 646$ & $-\$ 1,845$ \\
\hline
\end{tabular}

Present values are calculated using a $3 \%$ real interest rate.

diplomas only. The present value of the lifetime fiscal premium in UI is almost $\$ 1,200$ per bachelor’s degree and more than $\$ 1,800$ per professional and doctorate degree.

\section{Worker's Compensation}

Fiscal savings from college attainment are also created through worker'scompensation programs. In many states, however, worker's compensation is an offbudget item: some states operate worker's compensation through private insurance companies dealing directly with employers. The effects, however, are the same whether on or off budget. Thus, this study treats worker's compensation as an implicit fiscal item in all states. 
Table 11

Estimated Lifetime Worker's Compensation across Education Categories

\begin{tabular}{|c|c|c|c|c|c|}
\hline & High School & $\begin{array}{c}\text { Associate's } \\
\text { Degree }\end{array}$ & $\begin{array}{r}\text { Bachelor's } \\
\text { Degree }\end{array}$ & $\begin{array}{r}\text { Master's } \\
\text { Degree } \\
\end{array}$ & $\begin{array}{c}\text { Professional \& } \\
\text { Doctorate Degree }\end{array}$ \\
\hline Sum & $\$ 4,226$ & $\$ 3,472$ & $\$ 2,591$ & $\$ 2,654$ & $\$ 781$ \\
\hline Present Value & $\$ 1,671$ & $\$ 1,527$ & $\$ 1,073$ & $\$ 997$ & $\$ 300$ \\
\hline \multicolumn{2}{|c|}{ Degree Premium - Sum } & $-\$ 754$ & $-\$ 1,635$ & $\$ 63$ & $-\$ 1,810$ \\
\hline \multicolumn{2}{|c|}{ Degree Premium - PV } & $-\$ 144$ & $-\$ 599$ & $-\$ 76$ & $-\$ 772$ \\
\hline
\end{tabular}

Present values are calculated using a $3 \%$ real interest rate.

Average lifetime worker's compensation across education categories is reported in Table 11. Estimates for Wisconsin are shown in Appendix Table 3. These estimates are derived under the same assumption used for UI compensation: no worker's compensation is received while in college (it would be inconsistent to assume that some traditional fulltime students qualify for worker's compensation while in college). The estimated fiscal degree premia in worker's compensation are relatively the largest for bachelor's degrees and professional and doctorate degrees. The present value of the lifetime fiscal premium in worker’s compensation is about $\$ 600$ per bachelor’s degree and almost $\$ 800$ per professional and doctorate degree.

\section{Corrections}

Combining data from the Bureau of Justice Statistics’ Prisoners in 2005 (Harrison \& Beck, 2006b), the Census Bureau’s State and Local Government Finances: 2004-05, and the Office of Management and Budget's Budget of the United States Government (Table 3.2), indicates that average correctional expenditure per inmate was $\$ 29,877$ in 
fiscal year 2005. ${ }^{35}$ Cost per federal prisoner was $\$ 35,203$, and cost per state and local prisoner was \$29,538. ${ }^{36}$ A Bureau of Justice Statistics report (Harlow, 2003) using 1996 and 1997 data indicates that $0.115 \%$ t of the adult population with a bachelor's degree or higher is incarcerated in federal, state, and local prisons and jails. Among those with some college experience or associate's degrees, the incarceration proportion is $0.317 \%$.

For those with a high school diploma, the proportion is $1.191 \%$, which is 10.4 times higher than the proportion for bachelor's graduates. Thus, the differential in corrections costs is $\$ 321$ annually per bachelor’s degree $[\$ 29,877 \times(0.0191-0.0115)]{ }^{37}$

Table 12 Estimated Lifetime Corrections Costs across Education Categories

\begin{tabular}{lrrr}
\hline & High School & $\begin{array}{r}\text { Associate's } \\
\text { Degree }\end{array}$ & $\begin{array}{r}\text { Bachelor's } \\
\text { Degree or More }\end{array}$ \\
\hline \multirow{2}{*}{$\begin{array}{l}\text { Sum } \\
\text { Present Value }\end{array}$} & $\$ 21,702$ & $\$ 6,166$ & $\$ 2,697$ \\
& $\$ 10,202$ & $\$ 3,102$ & $\$ 1,576$ \\
\multicolumn{1}{c}{$\begin{array}{l}\text { Degree Premium - Sum } \\
\text { Degree Premium - PV }\end{array}$} & $-\$ 15,536$ & $-\$ 19,004$ \\
& $-\$ 7,100$ & $-\$ 8,626$ \\
\hline
\end{tabular}

Present values are calculated using a $3 \%$ real interest rate.

Table 12 reports estimates of average lifetime corrections costs across education categories. These estimates are derived under the same assumptions as for publicassistance programs. The estimates for associate’s degrees use the incarceration probability for some college and associate's degrees, which should understate its

\footnotetext{
${ }^{35}$ This cost per prisoner is calculated using all corrections costs, including probation. Thus, the resulting estimates of fiscal premia are for corrections costs rather than just prison costs. This interpretation imposes the implicit assumption that the probabilities of being on probation are roughly proportional to the probabilities of being incarcerated.

${ }^{36}$ Persons held in juvenile facilities were last estimated for fiscal year 2004. All persons in juvenile facilities are assumed to be under state and local jurisdiction.

${ }^{37}$ Moreover, prisoners (and homeless persons) are not included in the CPS. Sample selection in the CPS is not entirely independent of college attainment. Thus, the average high school graduate pays disproportionately less tax revenues than shown earlier. As a result, the preceding estimates of fiscal premia in tax revenues are understated to the extent that the CPS sample is not completely random with respect to college education.
} 
estimated fiscal premium somewhat (presumably, holders of associate’s degrees have a lower probability of being in prison than those with some college but no degree).

Estimates for bachelor's and advanced degrees are lumped together. Given the magnitude of the average incarceration cost for this group, this probably makes little difference.

Estimates for Wisconsin are shown in Appendix Table 3. The data do not allow estimation of college differentials in incarceration rates for individual states. Thus, the individual state estimates are derived by applying state-specific per-inmate $\operatorname{costs}^{38}$ to national-average differentials in incarceration rates. ${ }^{39}$ Unlike most of the other fiscal effects which accrue more at the federal level, the large majority of the fiscal benefits from college education accrue to state and local governments. Direct federal corrections expenditure is only 9\% of the national total in 2005.

The estimates of the fiscal premia in Table 12 and Appendix Table 3 err to the conservative to the extent that inmates with more education are less expensive to imprison. Among those in prison, those with at least some college experience are less likely to be there for violent crime. Thus, college-educated prisoners are probably somewhat less expensive. In addition, college educated prisoners are probably healthier, and hence create less prison healthcare costs (according to Stephan [2004], the costs of inmate medical care are $12 \%$ of total operating cost of prisons).

On the other hand, the issue of causation may be more problematic for corrections than for the other college differentials: individuals in prison may be disproportionately

\footnotetext{
${ }^{38}$ Estimates of incarceration cost per inmate for individual states in 2005 are derived using data from the Bureau of Justice Statistics' Prison and Jail Inmates at Midyear 2005 (Harrison \& Beck, 2006a), Office of Justice Programs' Juvenile Offenders and Victims: 2006 National Report (Snyder \& Sickmund, 2006), and the Census Bureau's State and Local Government Finances: 2004-05.

${ }^{39}$ Adult population proportions in state and local prisons and jails (i.e., not in federal prisons) are $1.122 \%$, $0.289 \%$, and $0.098 \%$ for high school diploma, college below a bachelor's degree, and bachelor's degree or higher, respectively.
} 
less educated because they were incarcerated, and/or the underlying reasons for imprisonment and low education are the same. Most individuals in prison started there at college age or younger. Lochner and Moretti (2004), however, present convincing evidence that the effect of education on the incidence of incarceration (and criminal behavior) is indeed causal. Moreover, Harlow (2003) reports that many prisoners take advantage of college and vocational courses offered in prisons; thus, it is possible that the simple correlation between education attainment and incarceration understates the causal effect.

\section{Public Healthcare}

In addition to Medicaid being negatively correlated with college attainment, the lack of any health insurance is negatively correlated with college attainment. Moreover, the uninsured impose significant costs on governments, although it is difficult, if not impossible, to identify these costs in government finance data. The fiscal costs created by the uninsured are implicitly small fractions of various spending categories (Medicare, Medicaid, Hospitals, Public Health, etc.). Hadley and Holahan (2003), however, provide an estimate of the governmental costs of the uninsured. They estimate the total government cost per uninsured to be just under $\$ 750$ (in 2001 dollars). In 2005 dollars (using the Consumer Price Index), this is $\$ 823$ per uninsured. The cost to the federal government is roughly \$535 per uninsured, and the cost to state and local governments is about \$288 per uninsured. Given that healthcare costs have generally risen faster than inflation, these estimates are probably on the conservative side. 
The incidence of uninsurance across education categories can be computed using CPS data. These estimates are reported in Table 13. Among those age 27 and older in 2005, 16.8\% of high school graduates with no college reported having no health insurance, more than double the percentage of those with bachelor's degrees without an advanced degree. Table 13 also reports estimates of the college premia in public healthcare costs from the lack of health insurance by assuming a constant average cost of $\$ 823$ per uninsured. However, given the positive relationship between college attainment and health, these estimates of the fiscal effects of college education are particularly conservative. ${ }^{40}$ That is, it is likely that the cost per uninsured is decreasing in college attainment, but this is not taken into account in the estimates. Otherwise, the estimates in Table 13 are calculated using the same assumptions about the timing of these costs over the lifecycle as for public-assistance programs. Corresponding estimates for Wisconsin are shown in Appendix Table 3. Unfortunately, in the absence of estimates for individual state estimates, the national-average state and local cost of $\$ 288$ per uninsured must be assumed for all states.

\footnotetext{
${ }^{40}$ Among the uninsured age 27 and older, 52\% of those with only a high school education report their health to be very good or excellent, compared to $65 \%$ for those with a bachelor's degree as their highest qualification.
} 
Table 13

Uninsurance Rates and Estimated Lifetime Public-Healthcare Costs across Education Categories

\begin{tabular}{|c|c|c|c|c|c|}
\hline & High School & $\begin{array}{r}\text { Associate's } \\
\text { Degree }\end{array}$ & $\begin{array}{r}\text { Bachelor's } \\
\text { Degree } \\
\end{array}$ & $\begin{array}{r}\text { Master's } \\
\text { Degree } \\
\end{array}$ & $\begin{array}{c}\text { Professional \& } \\
\text { Doctorate Degree }\end{array}$ \\
\hline Uninsured Percentage & $16.8 \%$ & $10.5 \%$ & $8.3 \%$ & $5.0 \%$ & $5.7 \%$ \\
\hline \multicolumn{6}{|l|}{ Public Healthcare Costs } \\
\hline Sum & $\$ 9,220$ & $\$ 5,488$ & $\$ 4,548$ & $\$ 3,255$ & $\$ 3,715$ \\
\hline Present Value & $\$ 5,811$ & $\$ 3,539$ & $\$ 2,892$ & $\$ 2,229$ & $\$ 2,536$ \\
\hline \multicolumn{2}{|c|}{ Degree Premium - Sum } & $-\$ 3,733$ & $-\$ 4,673$ & $-\$ 1,293$ & $-\$ 833$ \\
\hline \multicolumn{2}{|c|}{ Degree Premium - PV } & $-\$ 2,272$ & $-\$ 2,918$ & $-\$ 664$ & $-\$ 357$ \\
\hline
\end{tabular}

Uninsured percentages are for population age 27 and older. Present values are calculated using a $3 \%$ real interest rate.

As is the case for most public assistance programs, most of the estimated fiscal impact on public healthcare occurs for undergraduate degrees. The results in Table 13 reveal that the estimated average lifetime public healthcare cost for holders of associate's degrees is $60 \%$ as much as the average for holders of high school diplomas and no college. The average for bachelor's degrees is $49 \%$ as much as the average for high school diplomas. In present value, each associate’s degree reduces public healthcare costs by almost $\$ 2,300$, and each bachelor's degree reduces it by more than $\$ 2,900$.

\section{Public Cost per Degree}

Government Spending on College Education

Government spending on higher education is taken from Table 3.16 of the National Income and Product Accounts (NIPA). Arguably better data for state and local appropriations for higher education are available from the State Higher Education Executive Officers’ State Higher Education Finance (SHEF) project. Moreover, most 
government spending on higher education is at the state and local level. ${ }^{41}$ Nonetheless, this study relies on the NIPA data for two reasons. First, the NIPA data include federal spending on higher education and measures it and state and local spending on higher education using a consistent methodology. Second, the NIPA measure of state and local government spending on higher education is somewhat greater (specifically, 15.9\% greater) than the SHEF measure, thus producing a more generous estimate of the public cost per degree and hence a more conservative estimate of the fiscal rate of return.

The main reason for the discrepancy between the NIPA and SHEF measures of states and local funding for higher education is that the NIPA measure implicitly includes expenditures financed through revenues from public college endowments. The SHEF measure only includes state and local government appropriations for higher education. Thus, in terms of tax appropriations, the NIPA measure overstates the fiscal cost of college degrees by about $16 \%$. Rather than evaluate the relative merits of the different underlying concepts of public opportunity cost, this study simply chooses the more generous measure (i.e., more conservative measure in showing the fiscal return). ${ }^{42}$

The NIPA (as well as the SHEF) measure of the fiscal cost of college degrees is certainly generous in that it includes the costs of university research and service activities. Given that this study only attempts to quantify the fiscal payoffs from college attainment (rather than the fiscal payoffs from the higher education sector), the costs of research and service should be not be included. Data from the National Center for Education Statistics for academic year 2001 (the latest now available) indicate that

\footnotetext{
41 The NIPA data for calendar years 2002-2005 indicate that the federal share is about $19 \%$.

${ }^{42}$ One could reasonably argue that expenditures financed from publicly owned endowments are public contributions. One could also argue that many of these endowments are established through private donations.
} 
research and service accounted for $19.3 \%$ of total educational and general expenditures. Unfortunately, the percentages for individual states are not available.

On the other hand, the NIPA data are for current expenditures only. The NIPA does not separate capital expenditures in higher education from primary and secondary education. Data from the Census Bureau's State and Local Government Finances for fiscal years 2002-2005 on public higher education expenditures indicate that, at the state and local level, capital outlays are $13.5 \%$ as large as operating expenditures. Thus, taking the opposing effects of the inclusion of research and service costs and the exclusion of capital costs into account suggests that the measure of government spending on higher education is overstated by roughly $5.8 \%$.

The NIPA data on government funding for higher education are not available for individual states, though. When examining individual states, this study uses data from the Census Bureau’s State and Local Government Finances (SLGF). To be more specific, this study uses the SLGF state and local government expenditures on higher education less capital outlays on higher education and net of state and local government current charges in higher education (i.e., tuition, fees, revenues from auxiliary activities, etc.). Conceptually, these data should then be approximately equal to the NIPA data. Indeed, in fiscal years 2002-2005, the SLGF national measure differs from the NIPA measure of national state and local government spending on higher education by $-1.57 \%{ }^{43}$

\section{Government Cost per Degree}

\footnotetext{
${ }^{43}$ NIPA calendar year data are matched to SLGF fiscal year (ending June 30) data by averaging the appropriate calendar years’ data.
} 
Data on college degrees for each state are calculated using the National Center for Education Statistics’ Integrated Postsecondary Education Data System. ${ }^{44}$ Although most public funding for higher education is clearly directed toward students in public institutions, significant funding — particularly federal funding_also goes to students in private higher education. Unfortunately, the government cost data cannot be separated into the amounts going to students in public colleges and to students in private colleges. Thus, to err on the conservative side, this study compares public funding for higher education to degrees granted from public institutions only. This imposes the implicit assumption that financial aid to students in private colleges does not lead to any additional college attainment. Results are also presented when comparing government cost to all degrees, both public and private, but these are not generally emphasized.

Calculating cost per degree is also problematic because higher education costs are not assigned by degree level. Moreover, degrees are not earned within a fiscal year. The latter problem is not particularly troublesome, though, as the multi-year nature of degrees should be adequately accounted for by averaging government spending on higher education over the relevant preceding years. This study matches degrees awarded in academic year 2005 to average government funding for higher education in the preceding four fiscal years, 2002-2005 (thus putting the emphasis on four-year degrees rather than two-year degrees).

To deal with the former problem, instead of trying to assign separate costs to the different degree levels, this study makes the simple assumption that each year of college creates the same fiscal cost. As discussed below, this is somewhat conservative in

\footnotetext{
${ }^{44}$ Graduates from U.S. military colleges are not counted in the individual states, but are included in the national totals, as are graduates from colleges in Washington, DC.
} 
showing the fiscal return to public investment in college students. It is again assumed that associate's and master's degrees take two additional years of education, while bachelor's, professional, and doctorate degrees average four additional years of education.

Associate's and master's degrees thus count as half of a four-year degree. Table 14 shows the resulting estimates of federal, state and local, and total government costs per fouryear-equivalent degree from public institutions only and from all institutions. Appendix Table 4 shows the estimated state and local government cost per degree in Wisconsin. Given that these degrees are assumed to take four years of government funding, these tables also report the estimated costs per degree in terms of present discounted value at the beginning of college (at the beginning of graduate school in the case of the advanced degrees).

Table 14 Estimated Government Cost per Four-Year-Equivalent Degree

\begin{tabular}{llll}
\hline & Federal & $\begin{array}{c}\text { State } \\
\text { \& Local }\end{array}$ & Total \\
\hline Public Degrees Only & & & \\
Sum & & & \\
Present Value & $\$ 14,007$ & $\$ 60,566$ & $\$ 74,573$ \\
All Degrees & $\$ 13,407$ & $\$ 57,971$ & $\$ 71,378$ \\
Sum & & & \\
Present Value & & & $\$ 47,955$ \\
& $\$ 9,008$ & $\$ 38,948$ & $\$ 45,901$ \\
\hline
\end{tabular}

Present values are calculated using a $3 \%$ real interest rate.

The relative importance of the separate degree levels is taken into account by weighting the corresponding fiscal effects. That is, the fiscal weights for the college premia at each degree level are their proportions of total four-year-equivalent degrees (from public institutions). If, for example, bachelor's degrees are half of all four-year- 
equivalent degrees awarded in a particular state, then the estimates of the fiscal consequences of bachelor's degrees in that state receive a $50 \%$ weight in estimating the total fiscal consequences of public investment in higher education. ${ }^{45}$

The above framework does not account for the fact that the fiscal cost of each year of college education clearly increases with the level of college education. The yearly fiscal cost (at the state level) of a doctorate degree is clearly greater than for an associate’s degree. By not accounting for fiscal cost increases with degree levels, the estimate of the fiscal return to public investment in college education is conservative. This is because not factoring in fiscal costs increases with degree levels puts disproportionate fiscal weight on the lowest degree levels and too little weight on the highest level of degrees, and the largest fiscal impact per degree year is for professional and doctorate degrees, followed by bachelor's degrees. If the increasing fiscal cost with degree levels were taken into account, greater fiscal weight would be placed on the degrees with the highest fiscal return per degree year.

\section{Average Fiscal Rate of Return}

\section{Total Fiscal Effects}

Applying the fiscal weights just discussed to the fiscal premia for each degree estimated earlier yields the estimated fiscal impacts per four-year-equivalent degree. These are reported in Table 15. This table shows, for all levels of government, the weighted averages of the various fiscal effects presented in the Tax Revenues,

\footnotetext{
${ }^{45}$ Specifically, the fiscal weights nationally are $19.7 \%$ for associate's degrees, $65.3 \%$ for bachelor's degrees. $10.2 \%$ for master's degrees, and $4.7 \%$ for professional and doctorate degrees. The proportions for all degrees (not just those from public institutions) are, respectively, $16.0 \%, 64.7 \%, 12.9 \%$, and $6.4 \%$.
} 
Table 15

Estimated Lifetime Total Fiscal Effects per Four-Year-Equivalent Degree

\begin{tabular}{|c|c|c|c|c|}
\hline & \multicolumn{2}{|c|}{ Costs } & \multicolumn{2}{|c|}{$\underline{\text { Revenues }}$} \\
\hline & \multirow[b]{2}{*}{ Sum } & Present & & $\begin{array}{l}\text { Present } \\
\text { Value }\end{array}$ \\
\hline & & Value & Sum & Value \\
\hline State and Local Taxes & & & $\$ 118,019$ & $\$ 47,144$ \\
\hline Federal Income Taxes & & & $\$ 237,819$ & $\$ 100,569$ \\
\hline Federal Payroll Taxes & & & $\$ 115,442$ & $\$ 49,528$ \\
\hline Welfare & $-\$ 10,218$ & $-\$ 6,544$ & & \\
\hline Medicaid & $-\$ 20,763$ & $-\$ 12,021$ & & \\
\hline Social Security and Medicare & $-\$ 18,622$ & $-\$ 19,867$ & & \\
\hline Supplemental Security Income & $-\$ 5,749$ & $-\$ 3,129$ & & \\
\hline Unemployment Compensation & $-\$ 1,665$ & $-\$ 1,054$ & & \\
\hline Worker's Compensation & $-\$ 1,438$ & $-\$ 506$ & & \\
\hline Corrections & $-\$ 21,385$ & $-\$ 9,726$ & & \\
\hline Public Healthcare & $-\$ 4,828$ & $-\$ 2,974$ & & \\
\hline Totals & $-\$ 84,668$ & $-\$ 55,819$ & $\$ 471,281$ & $\$ 197,240$ \\
\hline \multicolumn{5}{|c|}{ Internal Rate of Return (public degrees only) $=10.3 \%$} \\
\hline Internal Rate of Return & s) $=13.7 \%$ & & & \\
\hline
\end{tabular}

Present values are calculated using a $3 \%$ real interest rate.

Governmental Expenditures, and Public Cost per Degree sections of this paper. Table 16 reports these weighted-average effects of college attainment accruing at the federal government level, and Table 17 shows these weighted-average effects of college education accruing to state and local governments. Appendix Table 4 shows the estimated state- and local-government effects per four-year-equivalent degree in 
Table 16

Estimated Lifetime Federal Fiscal Effects per Four-Year-Equivalent Degree

\begin{tabular}{|c|c|c|c|c|}
\hline & \multicolumn{2}{|c|}{ Costs } & \multicolumn{2}{|c|}{ Revenues } \\
\hline & \multirow[b]{2}{*}{ Sum } & \multicolumn{2}{|l|}{ Present } & \multirow{2}{*}{$\begin{array}{r}\text { Present } \\
\text { Value }\end{array}$} \\
\hline & & Value & Sum & \\
\hline Income Taxes & & & $\$ 237,819$ & $\$ 100,569$ \\
\hline Payroll Taxes & & & $\$ 115,442$ & $\$ 49,528$ \\
\hline Welfare & $-\$ 8,018$ & $-\$ 5,135$ & & \\
\hline Medicaid & $-\$ 12,442$ & $-\$ 7,203$ & & \\
\hline Medicare & $-\$ 9,518$ & $-\$ 10,619$ & & \\
\hline Social Security & $-\$ 9,104$ & $-\$ 9,248$ & & \\
\hline Supplemental Security Income & $-\$ 5,749$ & $-\$ 3,129$ & & \\
\hline Corrections & $-\$ 1,925$ & $-\$ 876$ & & \\
\hline Public Healthcare & $-\$ 3,139$ & $-\$ 1,933$ & & \\
\hline Totals & $-\$ 49,895$ & $-\$ 38,142$ & $\$ 353,262$ & $\$ 150,097$ \\
\hline \multicolumn{5}{|c|}{ Internal Rate of Return (public degrees only) $=24.8 \%$} \\
\hline Internal Rate of Return & s) $=29.7 \%$ & & & \\
\hline
\end{tabular}

Present values are calculated using a 3\% real interest rate.

Wisconsin. ${ }^{46}$ As discussed earlier, the state-level fiscal effects shown in Table 17 are reduced by $6.6 \%$ to account for interstate migration of college graduates. ${ }^{47}$ Table 15 shows that the largest fiscal payoff is clearly in the additional tax revenues from the

\footnotetext{
${ }^{46}$ To be consistent with this study's measure of cost per degree, Tables 15-17 and Appendix Table 4 show the present values of the fiscal premia for the graduate degrees relative to the assumed beginning of graduate school (i.e., the present values at age 23).

${ }^{47}$ This number is the sum of the estimated net migration rates from Trostel (2007) (3.4\% for associate's degrees, $7.1 \%$ for bachelor's degrees, $7.9 \%$ for master's degrees, and $9.6 \%$ for professional and doctorate degrees) times their respective weights (19.7\%, 65.3\%, 10.2\%, and 4.7\%). This number varies slightly in Appendix Table 4 because states have different proportions of degrees.
} 
higher incomes associated with college education. Indeed, $85 \%$ of the $\$ 556,000$ estimated cumulative fiscal effect over the lifetime of a four-year-equivalent degree is from additional tax revenues.

Table 17 Estimated Lifetime State and Local Fiscal Effects per Four-Year-Equivalent Degree

\begin{tabular}{|c|c|c|c|c|}
\hline & \multicolumn{2}{|c|}{ Costs } & \multicolumn{2}{|c|}{$\underline{\text { Revenues }}$} \\
\hline & Sum & $\begin{array}{c}\text { Present } \\
\text { Value }\end{array}$ & Sum & $\begin{array}{c}\text { Present } \\
\text { Value }\end{array}$ \\
\hline Income Taxes & & & $\$ 48,741$ & $\$ 20,699$ \\
\hline Property Taxes & & & $\$ 35,439$ & $\$ 12,842$ \\
\hline Sales Taxes & & & $\$ 25,357$ & $\$ 9,872$ \\
\hline Welfare & $-\$ 2,073$ & $-\$ 1,331$ & & \\
\hline Medicaid & $-\$ 7,814$ & $-\$ 4,534$ & & \\
\hline Unemployment Compensation & $-\$ 1,552$ & $-\$ 988$ & & \\
\hline Worker's Compensation & $-\$ 1,350$ & $-\$ 476$ & & \\
\hline Corrections & $-\$ 18,322$ & $-\$ 8,351$ & & \\
\hline Public Healthcare & $-\$ 1,593$ & $-\$ 983$ & & \\
\hline Totals & $-\$ 32,704$ & $-\$ 16,663$ & $\$ 109,536$ & $\$ 43,413$ \\
\hline \multicolumn{5}{|c|}{ Internal Rate of Return (public degrees only) $=3.1 \%$} \\
\hline Internal Rate of Return & s) $=5.1 \%$ & & & \\
\hline
\end{tabular}

Post-college fiscal effects are reduced by $6.6 \%$ to account for interstate emigration of graduates. Present values are calculated using a $3 \%$ real interest rate.

In terms of present value, using a 3\% real discount rate, the additional tax revenues are $78 \%$ of the $\$ 253,000$ total fiscal effect per degree. Although the effects of college attainment on the various government expenditures are small relative to the 
effects on tax revenues, they are not small relative to government expenditure on higher education. Indeed, the $\$ 84,700$ sum of expenditure savings over a lifetime exceeds the government cost of $\$ 74,500$ reported in Table 14 . The net public cost of higher education is negative. In present value when using a 3\% real discount rate, however, the total expenditure savings are less than the government investment per four-year-equivalent degree from public institutions.

Moreover, it should be kept in mind that these fiscal effects are estimated under numerous conservative consumptions. These estimates understate the fiscal effects for several reasons. The estimates ignore all fiscal benefits from college education that does not lead to a degree. Reductions in mortality rates associated with higher education are also ignored, as are all intergenerational effects. Savings in the administration of the various expenditure programs are not included. Some welfare programs are not included in the calculations. Only the direct fiscal effects from college attainment are captured (as opposed to potential indirect effects from higher education generally through innovation, job creation, and growth). Moreover, the estimates of government cost per degree are quite generous. Public costs of college education in private colleges are included, while those degrees are ignored. Expenditures financed from public college endowment revenues are included, as are expenditures on university research and service activities. Also, the assumption that all years of college impose the same public cost causes too little weight to be placed on the fiscal benefits from degrees with the largest fiscal effects (professional and doctorate).

On the other hand, it should also be kept in mind that these fiscal effects might not be so conservative for two reasons. First, the estimates for the effects on Social 
Security and Medicare spending are particularly uncertain, and these are fairly large relative to the other spending programs. Second, the estimates are for traditional college students, and the fiscal returns are lower for older college graduates.

The results reported in Table 15 suggest that the largest fiscal benefits accrue in federal programs while the government cost is concentrated at the state and local level. Thus, the fiscal return on investment in college education is much higher at the federal level than at the state level. Tables 16 and 17 show the magnitude of the difference.

Comparing Table 16 to Table 15 reveals that $72.5 \%$ of the total fiscal premium accrues at the federal level. ${ }^{48}$ In present value, $74.4 \%$ of the total fiscal premium is federal. But the federal government only picks up $18.8 \%$ of the estimated total public cost. In total undiscounted lifetime effects, the federal fiscal benefit of \$403,000 per degree is almost 29 times greater than the federal cost of $\$ 14,000$ per public-college degree, and almost 45 times greater than the federal cost for all degrees public and private.

Table 17 shows that the average fiscal impact at the state level is not nearly as dramatic, although the net lifetime impact of state and local government investment in college students is still positive. Appendix Table 4 reports the estimated lifetime fiscal effects per college degree in Wisconsin. In total undiscounted lifetime effects shown in Table 17, the state and local fiscal benefits of $\$ 142,000$ are 2.35 times greater than the state and local cost of \$60,500 per degree from public colleges, and 3.65 times greater than the state and local cost per degree from all institutions. Again, it should be kept in mind that these fiscal effects are conservatively estimated.

\footnotetext{
48 The numbers reported in Tables 16 and 17 do not sum to the totals reported in Table 15 because of the adjustment made for net migration of college graduates.
} 


\section{Fiscal Rates of Return}

In addition to presenting the estimates of the various weighted fiscal effects of college attainment, the bottom of Tables 15-17 and Appendix Table 4 report estimates of the real average fiscal internal rate of return implied by the cumulative fiscal effects shown in these tables along with the fiscal costs shown in Table 14 (at the top of Appendix Table 4). That is, these tables show the real (i.e., above inflation) average rate of return to government investments in college students. The internal rate of return estimates in Table 17 and Appendix Table 4 take into account average net interstate migration of college graduates.

The estimated overall average fiscal rate of return is, conservatively, $10.3 \%$. If degrees from private institutions are included in the public cost per degree, the government rate of return is $13.7 \%$. At the individual state level, the average internal rate of return is estimated to be $3.1 \%$ (5.1\% when including private degrees). Without the adjustment for interstate migration of college graduates, the average state rate of return per public degree is 3.5\% (5.5\% when including degrees from private colleges).

The time required to recoup the public investment in college students is remarkably short. Given the high fiscal payoffs to college attainment shown earlier, perhaps this is to be expected. For all levels of government combined, the public investment is recovered in less than 9.5 years after four-year-equivalent degree graduation. Public investment in a traditional college student is fully recovered just after age 31. At the state level, however, it takes more than 24 years (age 46) to recover the state and local investment (after taking net migration of college graduates into account). 
Figure 4 illustrates the time path of the total fiscal effects per four-year-equivalent degree begun at age 19 and completed at age 23. The government investment per degree reaches $\$ 90,000$ at college graduation (government spending per degree plus the reduced

\section{Figure 4}

Cumulative Fiscal Effect per Four-Year Equivalent Degree

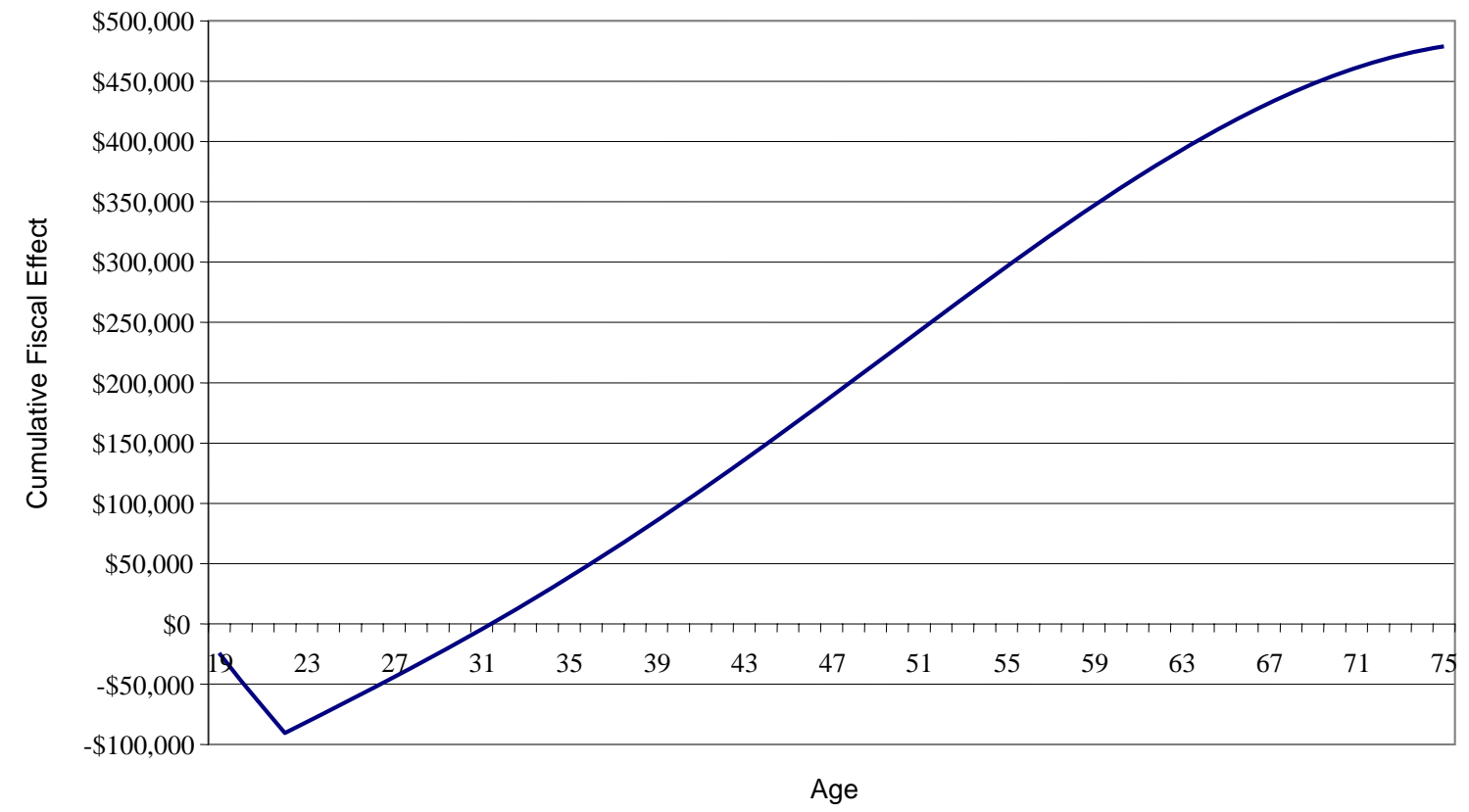

tax revenues while in college). That investment is recovered at age 31.5. The cumulative total fiscal premium per four year-equivalent-degree reaches $\$ 100,000$ at age 40, $\$ 200,000$ at age $48, \$ 300,000$ at age 55 , etc.

\section{Conclusion}

College education clearly creates substantial fiscal benefits for governments. This study has quantified these fiscal effects of college attainment more thoroughly than in previous literature. It quantifies more fiscal effects using a more systematic methodology and better data than in previous work. This study also carefully accounts for the timing of 
the fiscal benefits. Fiscal effects accruing to state and local governments are separated from those accruing to the federal government. Unlike in the previous work, this study estimates the separate fiscal effects from different types of college degrees, as well as their overall weighted average. The fiscal cost per degree is also quantified, which allows a fiscal rate of return to be calculated.

Consistent with the previous literature, public support for higher education appears to be a sound use of tax dollars. Although all of the fiscal effects of college education cannot be estimated with great precision due to numerous complicating factors, the return on public investment is evidently substantial. The average fiscal rate of return appears to be at least $10 \%$ above the rate of inflation, and this estimate is quite conservative for numerous reasons. It is difficult to imagine another type of investment that can systematically match this average return to public investment in higher education.

Furthermore, the $10 \%$ fiscal return estimate measures only the direct fiscal return from college attainment: indirect effects on tax revenues and government expenditures through higher education's effect on economic growth are not included. The estimated fiscal return also does not include any benefits from publicly sponsored university research, from university public service and extension activities, or from the effect of public colleges and college education on entrepreneurial activity and job creation. Nor does the return quantified in this study include the value of various other social benefits, such as knowledge creation and dissemination, lower crime, higher civic participation, and so on. In addition, the $10 \%$ estimate is the average rate of return. The marginal fiscal 
Working Paper Series

WP012: The Fiscal Impacts of College Attainment

Download at: http://www.wiscape.wisc.edu/publications/WP012

payoff to public support for higher education targeting individuals on the margin of college attendance is most likely considerably higher. 


\section{References}

Autor, D. H., Katz, L. F., \& Kearney, M.S. (2005). Trends in U.S. wage inequality: Reassessing the revisionists. National Bureau of Economic Research Working Paper No. 11627.

Barrow, L., \& Rouse, C. (2005). Does college still pay? Economists’ Voice, 2(4), 3.

Baum, S., \& Payea, K. (2004). Education pays: The benefits of higher education for individuals and society. Washington, DC: College Board.

Belfield, C. R., Nores, M., Barnett, S., \& Schweinhart, L. (2006). The High/Scope Perry Preschool Program: Cost-benefit analysis using data from the age-40 followup. Journal of Human Resources, 41(1), 162-90.

Bound, J., \& Turner, S. (2006). Cohort crowding: How resources affect collegiate attainment. National Bureau of Economic Research Working Paper No. 12424.

Brady, H., Hout, M., \& Stiles, J. (2005). Return on investment: Educational choices and demographic change in California's future. Berkeley, CA: Survey Research Center.

Card, D. (1999). The causal effect of education on earnings. In O. Ashenfelter \& D. Card (Eds.), Handbook of labor economics (Vol. 3A). Amsterdam: Elsevier Science.

Card, D., \& Lemieux, T. (2001). Can falling supply explain the rising return to college for younger men? A cohort-based analysis. Quarterly Journal of Economics, 116(2), 705-46.

Chevalier, A., \& Feinstein, L. (2006). Sheepskin or Prozac: The causal effect of education on mental health. Center for the Economics of Education working paper.

Currie, J. (2001). Early childhood education programs. Journal of Economic Perspectives, 15(2), 213-38.

Cutler, D. M., \& Lleras-Muney, A. (2006). Education and health: Evaluating theories and evidence. National Bureau of Economic Research Working Paper No. 12352.

Fernandez, R., \& Rogerson, R. (1995). On the political economy of education subsidies. Review of Economics Studies, 62(2), 249-62.

Freeman, R. (1976). The overeducated American. New York: Academic Press.

Fortin, N. M. (2006). Higher-education policies and the college wage premium: Crossstate evidence from the 1990s. American Economic Review, 96(4), 959-87. 
Goldhaber, D., \& Player, D. (2003). Analytical framework for assessing the potential return on a federal investment in the Alliance for Excellent Education's Every child a graduate. Washington, DC: Alliance for Excellent Education.

Groot, W., \& Maassen van den Brink, H. (2004). The health effects of education: survey and meta-analysis. Unpublished manuscript.

Hadley, J., \& Holahan, J. (2003). How much medical care do the uninsured use, and who pays for it? Health Affairs - Web Exclusive, 12 February.

Hansen, W. L., \& Weisbrod, B. A. (1969). Benefits, costs and finance of public higher education. Chicago, IL: Markham.

Harlow, C. W. (2003). Education and corrections populations. Washington, DC: Bureau of Justice Statistics.

Harmon, C., Oosterbeek, H., \& Walker, I. (2003). The returns to education: Microeconomics. Journal of Economic Surveys, 17(2), 115-56.

Harrison, P. M., \& Beck, A. J. (2006a). Prison and jail inmates at midyear 2005. Washington, DC: Bureau of Justice Statistics.

Harrison, P. M., \& Beck, A. J. (2006b). Prisoners in 2005. Washington, DC: Bureau of Justice Statistics.

Haveman, R. H., \& Wolfe, B. L. (1984). Schooling and economic well-being: The role of nonmarket effects. Journal of Human Resources, 19(3), 377-407.

Haveman, R., \& Wolfe, B. (1995). The determinants of children's attainments: A review of methods and findings. Journal of Economic Literature, 33(4), 1829-78.

Heckman, J. J., \& Masterov, D. V. (2004). The productivity argument for investing in young children. Invest in Kids Working Group Working Paper No. 5.

Hovey, H. A. (1999). State spending for higher education in the next decade: The battle to sustain current support. Washington, DC: National Center for Public Policy and Higher Education.

Institute for Higher Education Policy. (2005). The investment payoff: A 50-state analysis of the private and public benefits of higher education. Washington, DC: Author.

Juhn, C., Kim, D. I., \& Vella, F. (2005). The expansion of college education in the United States: Is there evidence of declining cohort quality? Economic Inquiry, 43(2), 30315. 
Kaiser Commission on Medicaid and the Uninsured. (2004). Medicaid facts. Washington, DC: Author.

Kane, T. J., Orszag, P. R., \& Apostolov, E. (2005). Higher education appropriations and public universities: Role of Medicaid and the business cycle. Brookings-Wharton Papers on Urban Affairs, 99-146.

Katz, L. F., \& Autor, D. H. (1999). Changes in the wage structure and earnings inequality. In O. Ashenfelter \& D. Card (Eds.), Handbook of labor economics (Vol. 3A). Amsterdam: Elsevier Science.

Krop, R. A. (1998). The social returns to increased investment in education: Measuring the effect of education on the cost of social programs. Santa Monica, CA: Rand.

Levin, H., Belfield, C., Muennig, P., \& Rouse, C. (2007). The costs and benefits of an excellent education for all of America's children. New York, NY: Center for BenefitCost Studies of Education.

Lleras-Muney, A. (2005). The relationship between education and adult mortality in the United States. Review of Economic Studies, 72(1), 189-211.

Lochner, L., \& Moretti, E. “The Effect of Education on Crime: Evidence from Prison Inmates, Arrests, and Self-Reports” American Economic Review, 2004.

Longanecker, D. (2006). A tale of two pities. Change, 38(1), 14.

Lynch, R. G. (2004) Exceptional Returns: Economic, fiscal, and social benefits of investment in early childhood development. Washington, DC: Economic Policy Institute.

McIntyre, R. S., Denk, R., Francis, N., Gardner, M., Gomaa, W., Hsu, F., \& Sims, R. (2003). Who pays? A distributional analysis of the tax systems in all 50 states $\left(2^{\text {nd }}\right.$ Ed.). Washington, DC: Institute on Taxation and Economic Policy.

McMahon, W. (2004). The social and external benefits of education. in G Johnes \& J Johnes, International handbook on the economics of education. Edward Elgar.

Mortenson, T. (1994). Federal income taxes paid by college educated workers 1970 to 1991. Postsecondary Education Opportunity, 28.

Mortenson, T. (2001). Individual economic welfare in the human capital economy 1973 to 2000. Postsecondary Education Opportunity, 114.

Murphy, K. M., \& Welch, F. (1990). Empirical age-earnings profiles. Journal of Labor Economics, 8(2), 202-29. 
O’Hara, A. (2004). New methods for simulating CPS taxes. U.S. Census Bureau Technical Paper.

Rizzo, M. (2004). The public interest in higher education” in Federal Reserve Bank of Cleveland, Education and economic development.

Snyder, H. N., \& Sickmund, M. (2006). Juvenile offenders and victims: 2006 national report. Washington, DC: Office of Justice Programs.

Stephan, J. J. (2004). State prison expenditures, 2001. Washington, DC: Bureau of Justice Statistics.

Strathman, J. G. (1994). Migration, benefit spillovers and state support of higher education. Urban Studies, 31(6), 913-20.

Topel, R. (2004). The private and social values of education” in Federal Reserve Bank of Cleveland, Education and economic development.

Trostel, P. A. (1997). The incentive effects of tax and educational policies. Policy Options, 54-7.

Trostel, P. A. (2003). The long-term economic effects of declining state support for higher education: Are states shooting themselves in the foot? Wisconsin Center for the Advancement of Postsecondary Education.

Trostel, P. A. (2007). The impact of new college graduates on intrastate labor markets. Wisconsin Center for the Advancement of Secondary Education Working Paper No. 11.

Trostel, P. A., \& Ronca, J. M. (2007). A simple unifying measure of state support for higher education. Wisconsin Center for the Advancement of Secondary Education Working Paper No. 7.

Wolfe, B. L., \& Haveman, R. H. (2003). Social and nonmarket benefits from education in an advanced economy. in Y. Kodrzycki, Education in the 21st Century: Meeting the Challenges of a Changing World, 2003.

Vernez, G., Krop, R. A., \& Rydell, C. P. (1999). Closing the education gap: Benefits and costs. Santa Monica, CA: Rand. 


\section{Appendix}

Appendix Table 1

Average Labor Earnings, Degree Premia, and Tax Revenue Differentials in Wisconsin in 2003-2005

\begin{tabular}{|c|c|c|c|c|c|}
\hline High School & Some College & $\begin{array}{c}\text { Associate's } \\
\text { Degree }\end{array}$ & $\begin{array}{c}\text { Bachelor's } \\
\text { Degree }\end{array}$ & $\begin{array}{r}\text { Master's } \\
\text { Degree }\end{array}$ & $\begin{array}{c}\text { Professional \& } \\
\text { Doctorate Degree }\end{array}$ \\
\hline Average Earnings & $\$ 27,628$ & $\$ 34,814$ & $\$ 44,080$ & $\$ 53,397$ & $\$ 107,006$ \\
\hline Degree Premium & $\$ 367$ & $\$ 7,552$ & $\$ 16,819$ & $\$ 18,584$ & $\$ 72,192$ \\
\hline Tax Revenue Differential (12.0\%) & $\$ 47$ & $\$ 973$ & $\$ 2,168$ & $\$ 2,395$ & $\$ 9,304$ \\
\hline
\end{tabular}

Appendix Table 2

Estimated Lifetime State and Local Taxes across Education Categories in Wisconsin

\begin{tabular}{|c|c|c|c|c|}
\hline & Associate's & Bachelor's & Master's & $\begin{array}{c}\text { Professional \& } \\
\text { Doctorate Degree }\end{array}$ \\
\hline High School & Degree & Degree & Degree & \\
\hline
\end{tabular}

$\underline{\text { Income Taxes }}$

\begin{tabular}{|c|c|c|c|c|c|}
\hline Sum & $\$ 58,519$ & $\$ 77,597$ & $\$ 116,321$ & $\$ 159,766$ & $\$ 171,131$ \\
\hline Present Value & $\$ 27,750$ & $\$ 36,516$ & $\$ 51,694$ & $\$ 67,696$ & $\$ 76,603$ \\
\hline Degree & & $\$ 19,078$ & $\$ 57,802$ & $\$ 43,444$ & $\$ 54,81$ \\
\hline Degree & & $\$ 8,766$ & $\$ 23,944$ & $\$ 16,002$ & $\$ 24,91$ \\
\hline
\end{tabular}

Property Taxes

\begin{tabular}{|c|c|c|c|c|c|}
\hline $\begin{array}{l}\text { Sum } \\
\text { Present Value }\end{array}$ & $\begin{array}{r}\$ 119,627 \\
\$ 50,194\end{array}$ & $\begin{array}{r}\$ 129,106 \\
\$ 54,431\end{array}$ & $\begin{array}{r}\$ 151,387 \\
\$ 63,114\end{array}$ & $\begin{array}{r}\$ 140,560 \\
\$ 61,410\end{array}$ & $\begin{array}{r}\$ 159,877 \\
\$ 62,272\end{array}$ \\
\hline \multicolumn{2}{|c|}{$\begin{array}{l}\text { Degree Premium - Sum } \\
\text { Degree Premium - PV }\end{array}$} & $\begin{array}{l}\$ 9,479 \\
\$ 4,237\end{array}$ & $\begin{array}{l}\$ 31,761 \\
\$ 12,920\end{array}$ & $\begin{array}{r}-\$ 10,827 \\
-\$ 1,703\end{array}$ & $\begin{array}{r}\$ 8,489 \\
-\$ 842\end{array}$ \\
\hline \multicolumn{6}{|l|}{ Sales Taxes } \\
\hline $\begin{array}{l}\text { Sum } \\
\text { Present Value }\end{array}$ & $\begin{array}{l}\$ 56,536 \\
\$ 29,257\end{array}$ & $\begin{array}{l}\$ 70,388 \\
\$ 34,394\end{array}$ & $\begin{array}{l}\$ 72,867 \\
\$ 34,984\end{array}$ & $\begin{array}{l}\$ 76,233 \\
\$ 36,459\end{array}$ & $\begin{array}{r}\$ 108,253 \\
\$ 48,806\end{array}$ \\
\hline \multicolumn{2}{|c|}{$\begin{array}{l}\text { Degree Premium - Sum } \\
\text { Degree Premium - PV }\end{array}$} & $\begin{array}{r}\$ 13,851 \\
\$ 5,136\end{array}$ & $\begin{array}{r}\$ 16,331 \\
\$ 5,727\end{array}$ & $\begin{array}{l}\$ 3,366 \\
\$ 1,474\end{array}$ & $\begin{array}{l}\$ 35,386 \\
\$ 13,822\end{array}$ \\
\hline \multicolumn{6}{|c|}{$\underline{\text { Total State and Local Taxes }}$} \\
\hline $\begin{array}{l}\text { Sum } \\
\text { Present Value }\end{array}$ & $\begin{array}{l}\$ 234,682 \\
\$ 107,201\end{array}$ & $\begin{array}{l}\$ 277,090 \\
\$ 125,341\end{array}$ & $\begin{array}{l}\$ 340,576 \\
\$ 149,792\end{array}$ & $\begin{array}{l}\$ 376,559 \\
\$ 165,565\end{array}$ & $\begin{array}{l}\$ 439,261 \\
\$ 187,681\end{array}$ \\
\hline $\begin{array}{l}\text { Degree } \\
\text { Degree }\end{array}$ & & $\begin{array}{l}\$ 42,409 \\
\$ 18,139\end{array}$ & $\begin{array}{r}\$ 105,894 \\
\$ 42,590\end{array}$ & $\begin{array}{l}\$ 35,983 \\
\$ 15,773\end{array}$ & $\begin{array}{l}\$ 98,685 \\
\$ 37,889\end{array}$ \\
\hline
\end{tabular}

Present values are calculated using a $3 \%$ real interest rate. 
Working Paper Series

WP012: The Fiscal Impacts of College Attainment

Download at: http://www.wiscape.wisc.edu/publications/WP012

Appendix Table 3

Estimated Lifetime State and Local Expenditures across Education Categories in Wisconsin

\begin{tabular}{|c|c|c|c|c|c|}
\hline & High School & $\begin{array}{c}\text { Associate's } \\
\text { Degree }\end{array}$ & $\begin{array}{r}\text { Bachelor's } \\
\text { Degree }\end{array}$ & $\begin{array}{r}\text { Master's } \\
\text { Degree }\end{array}$ & $\begin{array}{c}\text { Professional \& } \\
\text { Doctorate Degree }\end{array}$ \\
\hline \multicolumn{6}{|l|}{$\underline{\underline{\text { Welfare }}}$} \\
\hline Sum & $\$ 4,338$ & $\$ 2,377$ & $\$ 907$ & $\$ 719$ & $\$ 478$ \\
\hline Present Value & $\$ 2,603$ & $\$ 1,527$ & $\$ 508$ & $\$ 438$ & $\$ 276$ \\
\hline \multicolumn{2}{|c|}{ Degree Premium - Sum } & $-\$ 1,960$ & $-\$ 3,430$ & $-\$ 188$ & $-\$ 429$ \\
\hline \multicolumn{2}{|c|}{ Degree Premium - PV } & $-\$ 1,076$ & $-\$ 2,095$ & $-\$ 70$ & $-\$ 232$ \\
\hline \multicolumn{6}{|l|}{ Medicaid } \\
\hline Sum & $\$ 13,199$ & $\$ 11,100$ & $\$ 4,392$ & $\$ 1,769$ & $\$ 4,349$ \\
\hline Present Value & $\$ 7,449$ & $\$ 5,575$ & $\$ 2,643$ & $\$ 1,323$ & $\$ 1,864$ \\
\hline \multicolumn{2}{|c|}{ Degree Premium - Sum } & $-\$ 2,099$ & $-\$ 8,807$ & $-\$ 2,623$ & $-\$ 43$ \\
\hline \multicolumn{2}{|c|}{ Degree Premium - PV } & $-\$ 1,874$ & $-\$ 4,806$ & $-\$ 1,321$ & $-\$ 779$ \\
\hline \multicolumn{6}{|c|}{ Unemployment Compensation } \\
\hline Sum & $\$ 11,814$ & $\$ 10,846$ & $\$ 3,848$ & $\$ 1,927$ & $\$ 0$ \\
\hline Present Value & $\$ 6,334$ & $\$ 5,615$ & $\$ 2,232$ & $\$ 829$ & $\$ 0$ \\
\hline \multicolumn{2}{|c|}{ Degree Premium - Sum } & $-\$ 968$ & $-\$ 7,966$ & $-\$ 1,921$ & $-\$ 3,848$ \\
\hline \multicolumn{2}{|c|}{ Degree Premium - PV } & $-\$ 718$ & $-\$ 4,101$ & $-\$ 1,404$ & $-\$ 2,232$ \\
\hline \multicolumn{6}{|c|}{$\underline{\text { Worker's Compensation }}$} \\
\hline Sum & $\$ 2,617$ & $\$ 2,113$ & $\$ 2,200$ & $\$ 125$ & $\$ 0$ \\
\hline Present Value & $\$ 1,376$ & $\$ 1,184$ & $\$ 1,122$ & $\$ 39$ & $\$ 0$ \\
\hline \multicolumn{2}{|c|}{ Degree Premium - Sum } & $-\$ 503$ & $-\$ 417$ & $-\$ 2,074$ & $-\$ 2,200$ \\
\hline \multicolumn{2}{|c|}{ Degree Premium - PV } & $-\$ 192$ & $-\$ 254$ & $-\$ 1,083$ & $-\$ 1,122$ \\
\hline
\end{tabular}

Corrections

\begin{tabular}{|c|c|c|c|}
\hline Sum & $\$ 22,427$ & $\$ 6,190$ & $\$ 2,586$ \\
\hline Present Value & $\$ 10,543$ & $\$ 3,123$ & $\$ 1,537$ \\
\hline \multicolumn{2}{|c|}{ Degree Premium - Sum } & $-\$ 16,236$ & $-\$ 19,840$ \\
\hline \multicolumn{2}{|c|}{ Degree Premium - PV } & $-\$ 7,420$ & $-\$ 9,006$ \\
\hline
\end{tabular}

Public Healthcare

\begin{tabular}{|c|c|c|c|c|c|}
\hline Sum & $\$ 2,598$ & $\$ 1,694$ & $\$ 1,413$ & $\$ 1,216$ & $\$ 1,195$ \\
\hline Present Value & $\$ 1,689$ & $\$ 1,096$ & $\$ 970$ & $\$ 814$ & $\$ 922$ \\
\hline \multicolumn{2}{|c|}{ Degree Premium - Sum } & $-\$ 904$ & $-\$ 1,185$ & $-\$ 197$ & $-\$ 218$ \\
\hline \multicolumn{2}{|c|}{ Degree Premium - PV } & $-\$ 592$ & $-\$ 718$ & $-\$ 156$ & $-\$ 48$ \\
\hline \multicolumn{6}{|c|}{ Total State and Local Expenditures } \\
\hline Sum & $\$ 56,992$ & $\$ 34,321$ & $\$ 15,348$ & $\$ 5,757$ & $\$ 6,023$ \\
\hline Present Value & $\$ 29,992$ & $\$ 18,120$ & $\$ 9,012$ & $\$ 3,442$ & $\$ 3,061$ \\
\hline \multicolumn{2}{|c|}{ Degree Premium - Sum } & $-\$ 22,671$ & $-\$ 41,645$ & $-\$ 9,591$ & $-\$ 9,325$ \\
\hline \multicolumn{2}{|c|}{ Degree Premium - PV } & $-\$ 11,872$ & $-\$ 20,979$ & $-\$ 5,570$ & $-\$ 5,951$ \\
\hline
\end{tabular}

Present values are calculated using a $3 \%$ real interest rate.

*Estimates for Corrections and Public Healthcare are based on national averages

${ }^{\star *}$ Corrections estimates combine Bachelor's and advanced degrees. 
Appendix Table 4

Estimated Lifetime Fiscal Effects per Four-Year-Equivalent Degree in Wisconsin

\begin{tabular}{|c|c|c|c|c|}
\hline & \multicolumn{2}{|c|}{ Costs } & \multicolumn{2}{|c|}{ Revenues } \\
\hline & Sum & $\begin{array}{c}\text { Present } \\
\text { Value }\end{array}$ & Sum & $\begin{array}{r}\text { Present } \\
\text { Value }\end{array}$ \\
\hline Cost per Public Degree & $\$ 72,634$ & $\$ 69,522$ & & \\
\hline Cost per (all) Degree & $\$ 54,007$ & $\$ 51,693$ & & \\
\hline Income Taxes & & & $\$ 52,900$ & $\$ 22,311$ \\
\hline Property Taxes & & & $\$ 22,063$ & $\$ 9,079$ \\
\hline Sales Taxes & & & $\$ 16,788$ & $\$ 6,043$ \\
\hline Welfare & $-\$ 2,928$ & $-\$ 1,746$ & & \\
\hline Medicaid & $-\$ 6,909$ & $-\$ 4,054$ & & \\
\hline Unemployment Compensation & $-\$ 6,045$ & $-\$ 3,316$ & & \\
\hline Worker's Compensation & $-\$ 849$ & $-\$ 471$ & & \\
\hline Corrections * & $-\$ 21,620$ & $-\$ 9,852$ & & \\
\hline Public Healthcare * & $-\$ 1,111$ & $-\$ 696$ & & \\
\hline Post-college Totals & $-\$ 39,462$ & $-\$ 20,135$ & $\$ 91,752$ & $\$ 37,433$ \\
\hline & e of Return & rees only) $=$ & & \\
\hline & e of Return & s) $=3.5 \%$ & & \\
\hline
\end{tabular}

Post-college fiscal effects are reduced by $6.7 \%$ to account for net emigration of graduates. Present values are calculated using a $3 \%$ real interest rate.

*Estimates for Corrections and Public Healthcare are based on national averages. 